\title{
UNIVERSITYOF
}

FORWARD

THINKING

WESTMINSTER用

WestminsterResearch

http://www.westminster.ac.uk/westminsterresearch

Retirement Saving in the UK: a Life-Cycle Analysis

Adami, R., Carosi, A. and Sharma, A.

This article is (C) Emerald and permission has been granted for this version to appear here http://westminsterresearch.wmin.ac.uk/19973/

Emerald does not grant permission for this article to be further copied/distributed or hosted elsewhere without the express permission from Emerald Group Publishing Limited.

The final, published version will be published at:

https://dx.doi.org/10.1108\%2FSEF-01-2017-0018

The WestminsterResearch online digital archive at the University of Westminster aims to make the research output of the University available to a wider audience. Copyright and Moral Rights remain with the authors and/or copyright owners.

Whilst further distribution of specific materials from within this archive is forbidden, you may freely distribute the URL of WestminsterResearch: ((http://westminsterresearch.wmin.ac.uk/)).

In case of abuse or copyright appearing without permission e-mail repository@westminster.ac.uk 


\section{Retirement Saving in the UK: a Life-Cycle Analysis}

\begin{tabular}{|r|l|}
\hline Journal: & Studies in Economics and Finance \\
\hline Manuscript ID & SEF-01-2017-0018.R4 \\
\hline Manuscript Type: & Research Paper \\
\hline Keywords: & Life Cycle, Cultural differences, Retirement Saving \\
\hline \multicolumn{2}{|l}{} \\
\hline
\end{tabular}

SCHOLARONE $^{\text {In }}$

Manuscripts 


\section{Abstract}

Purpose - This paper studies long term savings accumulation in the UK. We use crosssectional information from the extensive dataset of the Family Resources Survey to compare long term saving amongst different ethnic groups with our control group, the native population. We reflect on whether different groups are more likely to suffer poverty in retirement.

Design / Methodology / Approach - In our analysis we apply the life cycle framework to explain saving profiles. This theoretical model has been used extensively in the field of economics and can be applied to empirical studies to examine changes in income and saving patterns over the life-course. The framework contends that individuals make savings decisions to smooth consumption over different phases of their life-cycle.

Findings - Our findings indicate that socio-economic factors are key elements in determining whether individuals plan for retirement, if factors are controlled for the differences in saving behaviours between ethnic minorities and the control population decrease considerably. Asian women, with good education and social standing display greater saving rates than the control group, while the socio-economic disadvantage suffered especially by Pakistani and Bangladeshi women is key to their inability to save long-term. High levels of poverty in retirement are more likely to be caused by the interaction of low levels of education, part-time work and long spells of unemployment than by ethnicity.

Originality I Value - Our important contribution to the debate on savings by ethnic minorities is the extension of the life-cycle model to specific sections of the population, to proffer new insights into their saving / dis-saving patterns, and ultimately their welfare in retirement.

JEL: J15, J16, D01

Keywords: Cultural Differences, Retirement Saving, Life Cycle 


\section{Introduction}

The recent trends in welfare cuts, implemented by many western governments, often imply a shift of responsibility for retirement income onto the individual through private pensions and personal saving schemes. The importance of understanding saving behaviours across sections of the population cannot be underestimated (Tavor and GarynTal, 2016) as many employers in the UK are also seeking to ameliorate the costs and risks of Defined Benefit pension schemes by replacing them with Defined Contribution schemes. The changes to public and occupational pension schemes introduced recently in the UK imply a transfer of risk and responsibility for retirement income from state and employers to individuals / employees. Further, the low private pension coverage amongst low earners is regarded to be a contributing factor to the high levels of pensioners' poverty (Barr and Diamond, 2008).

Although over the last decades many aspects of the lives of ethnic minorities in the UK have improved owing to greater integration and multiculturalism, there is extensive recent evidence that some disadvantage still exists, as poorer job opportunities, interrupted job histories, greater levels of self-employment and unemployment are more frequent amongst ethnic groups (Malveaux 1999; Clark and Drinkwater 2000; Blackaby et al. 2002; Cabinet Office 2003; Pensions Policy Institute 2003; Hoque and Noon, 2004, Vlachantoni et al. 2017). Reduced financial resources as well as cultural values and norms contribute to the disadvantage observed in long-term saving and retirement income of ethnic minorities compared with the white majority (e.g. Patrinos 1997; Bauer and Zimmermann 1997; Crossan et al. 2011; Lusardi and Mitchell, 2011a, 2011b; Lusardi et al. 2012; Seto and Bogan 2013; Feldmann 2013; Kandil 2015). Previous literature shows persistent trends of disadvantage in the labour market for minority ethnic groups, which is often perpetuated in retirement (Johnson 2004; Lewis and Lloyd-Sherlock, 2009; Börsch-Supan et al. 2009).

Whilst the relative position of different groups varies depending on the specific labour market indicator chosen, some broad trends can be established from the literature. Large scale social surveys show that white Britons tend to fare best on indicators such as 
employment rates and income, with Black Caribbean men, Indian women, and Black Africans occupying intermediate positions, while those of Pakistani and Bangladeshi descent exhibit the weakest labour market attachment (see Modood et al, 1997; Blackaby et al, 2002; Lindley et al. 2006; Dale et al, 2006; Salway et al., 2007). There is also conclusive evidence of significant gender effects (Bradley and Healy, 2008) and inter-group differences in the labour market indicating that Pakistani and Bangladeshi women are the most likely to suffer greater difficulties during their working lives as well as in retirement (Ginn and Arber, 2001). In their study on Ethnicity and Gender, Bradley and Healy (2008) show that Pakistani women' unemployment rate in 2004 stood at 20.2 percent, over 10 percentage points higher than Pakistani men and over 16 percent more than their white counterparts.

We use information on cross-sectional data from the Family Resources Survey to investigate savings accumulation for different ethnic and gender groups and reflect on the extent to which they are likely to suffer poverty in retirement (e.g., Guiso et al. 2003). The study applies the life-cycle framework to provide important new empirical evidence on the saving behaviour of ethnic minorities based on demographic and socio-economic characteristics and compares the saving behaviour of ethnic minorities to a control group, the white population. After examining the characteristics that emerge from our data we provide an understanding of the social and demographic factors that affect saving profiles over individuals' life course and find that socio-economic characteristics rather than ethnicity itself are key factors in determining whether individuals plan adequately for retirement.

The theoretical framework for our empirical analysis is the life cycle model that stems from Ando and Modigliani's 1963 study and has been used extensively in the field of saving, for example Alessie et al. (1997), Tin (1998), Banks et al. (1998), Jappelli (1999) (2005), Russo and Gandar (2003), Smith (2006), Blau (2008) amongst others.

Our first important contribution to the debate on savings by ethnic minorities is the extension of the life-cycle model to specific sections of the population, to proffer new insights into their saving / dis-saving patterns, and ultimately their welfare in retirement. We present strong empirical evidence that the differences in saving behaviours are primarily 
consequences of differences in education, income and employment status. A second, significant contribution is represented by the empirical analysis on ethnic minorities using a wealth of information from secondary data, while, typically, in past studies, much of the emphasis for accumulating data on ethnic minorities has relied on the analysis of qualitative data.

In accordance with the life-cycle framework, our study assumes that individuals make rational and informed saving decisions by optimising wealth over their lifetime. Rationality of retirement and long-term saving decisions is supported by the findings of Tavor and GarynTal (2016) in their recent qualitative study where they examine risk tolerance and rationality in retirement decision-making. Further, Winter et al. (2012) also address the important question of whether, in practice, individuals are more likely to use the rule of thumb rather than rational behaviour in their financial decisions. They suggest that the main saving considerations at the basis of the classical life-cycle model can be addressed by implementing rules of thumb rather than complex financial optimisation problems without great utility loss. We believe that this offers some support to the predictions offered by the life-cycle model even when its assumptions are not guaranteed.

To obtain a better understanding of economic diversity amongst ethnic minorities, we investigate saving participation rates and amounts across the life-cycle and compare them with the majority white population. We provide an in-depth analysis of how different ethnic minority groups plan for retirement through personal savings and test the significance of demographic and socio-economic variables in determining saving behaviours. We focus on saving patterns as a function of age (by controlling for generational differences) which allows us to determine specific saving profiles by ethnic background. Although we find that women of Pakistani and Bangladeshi origins are still the least likely to save for retirement, primarily owing to their disadvantage in terms of education, number of children and employment status, we show that, once we control for socio-economic factors, ethnic groups accumulate financial assets as much if not more than the control group.

The paper is structured as follows: Section 2 reviews the current literature on saving 
behaviours; Section 3 describes the survey and data sample; section 4 discusses the application of the life-cycle model; section 5 analyses the findings; section 6 concludes.

\section{Previous Research}

The relationship between income and saving accumulation has been the focus of an extensive body of literature, where the life-cycle model has often been used as theoretical framework, since Modigliani and Brumberg's study was published in 1954. Empirical research, however, has so far, led to mixed or inconclusive results, especially when trying to explain saving patterns for low-income individuals (Sherraden and Barr, 2005; Han and Sherraden, 2009). The link between income and saving levels, although important, is often rendered ambiguous by the combined effects of factors such as perceived uncertainty about future income, tax incentives to save and generosity of welfare. The effects of uncertainty about future income on precautionary savings was recently examined by Mastrogicomo and Alessie (2013), who use objective life-cycle income variations as well as subjective expectations about the future to reconcile past conflicting attempts to ascertain the levels of precautionary saving as proportion of total household savings.

Income and savings are also strictly linked to employment status and continuity. Some of the issues commonly raised when discussing ethnic minorities' status in the labour market include migration, stereotyping, alienation, family formation, structure of the economy and discrimination (Berthoud 2000). Berthoud's research highlights how young men from ethnic minority backgrounds face employment penalties in the UK, by using data from the Labour Force Survey. The age, migration history, educational qualifications and family structures of men in their 20 s and 30 s are analysed showing the contrasts between economic positions of different ethnic groups. Berthoud's findings show that for those of Indian and Chinese background employment rates are similar to those of the white population, while African-Caribbean, Africans, Pakistanis and Bangladeshi groups fare worse in terms of full time employment.

Berthoud indicates that although differences in generations may be relevant in some 
cases, for other ethnic groups the comparison between first and second-generation migrants does not show considerable change in fortune over the years. This is also confirmed by Blackaby et al. (2005), who find that young African-Caribbean men show a continuation of employment penalty; by contrast, Indian and Chinese men have managed to overcome the ethnic penalty and improve their job prospects largely through education.

A study conducted by Bradley and Healy (2008) on the effects of ethnicity and gender in employment in the UK shows that not only employment rates amongst ethnic minorities, especially amongst Pakistani and Bangladeshi were significantly lower than average (46 and 42 percent compared to an overall rate of 76 percent) but also that women belonging to these groups fare particularly unfavourably. An interesting finding from this study is that the percentages of ethnic minority women in part-time work, although still considerably higher than men's, is slightly lower than their native counterparts. The authors suggest that this is more likely to be the result 'of discrimination rather than choice' but also that it may be affected by factors such as the lack of the 'ability of male partners to find work or cultural values', which emphasise the importance of work, especially amongst Indian and Caribbean women.

With regard to the large proportions of Pakistani and Bangladeshi women excluded from formal employment (however they may be working in the family business) Salway (2006) indicates that it may be a reflexion of class and education, as shown by the low numbers of women in these groups in Higher Education (HE) or with HE qualifications. Another possible explanation can be found in the significantly high proportion of married women in these groups (especially if compared to their white counterparts), whereby, once married, many decide not to work. In their case it appears that cultural norms can work as deterrent to work outside the home, especially after marriage, this is also supported by Bradley et al. (2007), who find that many types of formal employment are perceived to be irreconcilable with domestic responsibilities. Inversely, education, employment and social status are deemed highly important in Indian families and cultures, which is reflected in comparatively high employment rates as well as in earnings that are more in line with the 
national average. Cultural background is also likely to be a key factor in the success of Caribbean women, both in education and in employment. As many come from very poor families, where mothers are often central / focal figures, girls of Caribbean origin are often brought up to be independent and focussed on educational success as a way to achieve independence and advantageous work conditions.

The heterogeneity in economic performance amongst ethnic minorities in the UK has also been confirmed by recent findings by Battu and Zenou (2010) as well as by Gough and Adami (2013). Battu and Zenou (2010) argue that some groups have a tendency to perpetuate isolation across generations and therefore affect their opportunities in terms of employment. Their findings concur with Gough and Adami's, who, in their study on ethnic minorities' retirement saving, show that while those of Indian and Chinese origins have experienced great improvements in terms of employment, income and long term savings since the 1990s, Pakistani and Bangladeshi still suffer a significant disadvantage in employment which affects their ability to save for retirement. The link between the discrimination suffered by some ethnic groups in the labour market and low saving for pension was also examined by Ginn and Arber in 2001. One of Ginn and Arber's key findings was that ethnicity and gender interact to generate a hierarchy where white men and Bangladeshi women feature the highest and lowest private pension coverage respectively.

Research also shows that ethnic minorities are more likely to be self-employed. There are two sets of causal factors at play here, a 'push factor' whereby ethnic minorities become self-employed due to labour market obstacles, for example discrimination often gives rise to this rational response. The second factor is a 'pull factor' and means that living in areas where many share similar cultural values provides a good environment within which to flourish as a local entrepreneur by virtue of a self-sustaining economy, informal sources of finance, shared religion and language, family support (Clark and Drinkwater, 2000).

Kempson (1998) showed that ethnic groups are also less likely to save through formal channels and investment products compared to the white population. A great deal of money, for example, is channelled into informal mutual savings and insurance associations 
with investment in property and businesses more widespread amongst ethnic groups than amongst the population as a whole.

In keeping with Kempson's findings, Nesbitt and Neary (2001) find evidence of alternative investments when studying older Pakistani and Bangladeshi men, who often do not contribute to a private pension due to the nature of their work. Furthermore, culturally, it is also deemed wise to 'invest' in one's children, where inter-generational money transfers can serve as insurance for family members and flow back from adult children to their parents if needed (Frankenberg et al. 2002). Large families and elaborate social networks are perceived to be obstacles to making adequate saving for retirement through established financial intermediaries, but they also represent informal safety nets that protect older family members from poverty in old age. Similar interpretations are confirmed by a recent study on saving patterns of ethnic minorities in Britain by Khan (2010), who finds that the proportion of Asian and Black British respondents with no savings stands at over $60 \%$, twice the rate of the white British population, with savings held in a very narrow range of products. The author, however, also suggests that informal saving practices are often used. These can take the form of investment in family business or money transfers between family members, which is part of many ethnic groups' cultural heritage, although family support obligations can vary significantly across cultures (Agree et al. 2005).

Furthermore, education and social class have been shown to affect financial capability amongst ethnic groups as sometimes language or cultural barriers may limit access to formal saving vehicles. Lusardi and Mitchell (2007) and Van Rooij et al. (2012) examine extensively the importance of financial literacy on wealth. Both studies find a strong and robust evidence of the positive effect that financial knowledge has on retirement planning and savings. Van Rooij et al. explain this effect stating that financial education reduces the costs incurred to access and process financial information and by doing so it facilitates financial decisions on saving and retirement plans.

Educational and occupational backgrounds correlate with earnings, incomes and savings throughout life. Economic disadvantage during the life course is often influenced by 
ethnicity and gender. In the case of ethnic minorities, it has been said that 'all to a greater or lesser extent are disadvantaged through an interaction between social policies and their 'otherness' by living in a foreign country' (Warnes et al., 2004).

\section{The Family Resources Survey Data}

This study uses data from the Family Resources Survey (FRS), in which we examine 14 waves of cross-sectional individual-year observations from 1994 to 2008. The FRS provides data over a longer timeframe than the English Longitudinal Study of Ageing (ELSA) and more relevant detail on ethnicity and pensions than other datasets such as the British Households Panel Survey (BHPS) and the Labour Force Survey (LFS). The FRS is an extensive, nationally representative, annual dataset that includes detailed financial and demographic data for a large sample of people resident in the UK. The survey is designed to provide information about living standards and the effectiveness of the social security system and is produced by the Department for Work and Pensions (DWP). It uses a two-stage stratified random sample drawn from the small users' Postcode Address File (PAF). Adults aged 16 and above are interviewed each year. The sample size increased over the years from 25,000 households in 1997 to 44,734 in 2008 , with an overall response rate ranging between $58 \%$ in 2008 and $69 \%$ in 1994 (FRS, 2011) ${ }^{1}$.

In order to obtain reliable results on people of ethnic background we combine observations for adults aged 16 and above for the years 1994 to 2008 . Our initial sample consists of 653,188 individuals, with over 4 per cent of the overall sample being represented by ethnic minority respondents - 47 per cent of respondents in our sample are men $(306,890)$ and 53 per cent are women $(346,298)$. The method of combining independent cross-sectional data is used to obtain larger samples (Jappelli, 1999; Ginn and Arber, 2001) and is particularly useful when studying minority groups. A low response rate to the FRS

\footnotetext{
1 FRS Technical Reports, http://www.statistics.gov.uk/StatBase/Product.asp?vlnk=9267 accessed July 2011.
} 
among ethnic minorities could tend to underestimate the extent of disadvantage in employment and private saving among these groups.

The FRS is an important source of demographic and socio-economic data. For the purpose of this study the sample is initially broken down by ethnicity, age, gender and employment. We arrange respondents into nine ethnic groups: Indian, Pakistani, Bangladeshi, Chinese, Black Caribbean, Black African, Any Other Asian, Any Other Black and the control group, the white population. The age cohorts are 16-24, 25-34, 35-44, 45-54, 55-64 and 65+. The sample is also divided according to employment status, which includes those in 'full time employment', 'full time self-employment', 'part-time employment', 'unemployed' and 'not working for other reasons'. The self-employed classification relates to the legal or 'business' perspective of employment. Individuals in the FRS are asked to classify themselves as self-employed using the question, 'Are you working as an employee or self-employed (including Business Start-Up)'. The FRS includes information on earnings for all respondents, whether they classify themselves as employed or self-employed.

Table 1 shows our sample according to age, gender, ethnic background and employment.

[Insert Table 1 here]

White men show the highest percentages of those in full time employment across all ages except those aged above 55. High percentages of men in full time employment are also found amongst respondents of Indian and Chinese origins, while Pakistani and Bangladeshi men feature the lowest full time employment rates and the highest percentages of part timers across all age cohorts. Pakistani men also show the highest proportions of self-employed (up to the age of 54). The consequences of this apparent disadvantage experienced by some ethnic groups in the labour market place are crucial in terms of tendency and ability to save for the future. Our data indicates that potentially a higher proportion of white men have access to private saving schemes throughout their working life. 
The higher proportions of those in work after the age of 55 amongst ethnic minorities could be at least partially explained by the necessity rather than the choice to work longer.

The results for women show less heterogeneity. Many women belonging to ethnic minorities are in employment across most age groups. The high percentage of women in full time or part time employment reflects the important changes that have occurred in the UK labour market in the last two decades (Ginn and Arber, 2001). The proportions of those in part time employment, self-employed and not in work, however, are significantly higher amongst Pakistani and Bangladeshi women, who also feature the lowest full time employment rates.

These preliminary results are consistent with Berthoud's (2000) and suggest that Pakistani and Bangladeshi men and women are more likely to be in part time employment, self-employed and experience interrupted work histories. The disadvantage they experience in the workplace may increase the probability of experiencing poverty in retirement or achieving adequate pension entitlements, owing to reduced access to private pension schemes.

\section{Method}

Changes in income and saving patterns over the life-course, including retirement, have been documented in a number of studies (Browning and Lusardi, 1996; Alessie et al., 1997; Banks et al. 1998). The life-cycle theory has its roots in the early papers of Modigliani and Brumberg (1954) and Friedman (1957) and has since been applied by economists to explain the inter-temporal allocation of financial resources across individuals' life-span (Browning and Crossley, 2001). It contends that agents (individuals or households) make savings decisions in order to smooth consumption over different phases of their life-cycle. Different models stemming from this conceptual framework have been tested empirically so far. Within the realm of saving - wealth accumulation over the life course in the UK, Banks et al. (1998) apply the life-cycle model to study how households de-cumulate wealth around retirement, while Browning and Crossley (2001) test patterns of income and consumption for 
households using the Family Expenditure Survey. Chetty et al. (2014) have also recently used the neoclassical life-cycle model to support the findings of their study on retirement saving decisions in Denmark.

We apply the life-cycle framework to explain saving profiles of ethnic minorities. The importance of our analysis lies in the evaluation of whether ethnic minorities are more likely than the rest of the population to be at risk of poverty once in retirement. We examine their saving participation rates and values saved throughout their life. The use of cross-sectional data raises the issue that the individuals interviewed at any point in time belong to different generations for which characteristics such as mortality rates, pension policies, productivity and saving rates may differ. This makes it hard to determine whether declines in saving rates in older respondents are a consequence of lower productivity or whether they are part of the dis-saving behaviour advocated by the life-cycle. To control for cohort effects we use a time series of cross sections (see Jappelli, 1999). With this method, cohorts can be tracked over time and therefore controlled.

We specify the saving participation ratio over the life course, with a dependent dummy variable (the probability to save) that can only take one of two possible values, 1 if the respondent saves an amount greater than zero, 0 otherwise. The probability to save is specified as a function of a polynomial in age, a matrix of socio-economic variables, such as total income (in linear and quadratic terms), employment ${ }^{2}$ and education ${ }^{3}$; a cohort

${ }^{2}$ For the purpose of the regression analysis we re-code employment status into three dummy variables: Full Time employment ( $x=1$ if employed or self-employed full time, $x=0$ otherwise); Part Time employment $(x=1$ if employed or self-employed part time, $x=0$ otherwise $)$ and Not in Employment ( $x=1$ if unemployed, $x=0$ otherwise).

${ }^{3}$ We use dummy variables to code Education and divide our sample into those with Low Education and those with High Education background. Using FRS data we classify as Low Education School and sandwich course certificates. High Education is defined as university or college degrees, qualification in nursing or similar, open college courses, open-university, correspondence course, any 
polynomial specified by the respondent's year of birth ${ }^{4}$, and a set of fixed time effects. To further enhance the robustness of our model we another three independent dummy variables, found to be significant in explaining saving behaviour in previous studies, these are whether the respondent has children, marital status and social class.

In our second regression the dependent variable is the logarithm of total private savings (the sum of an individual's financial assets) and, for each respondent, is a function of the same factors used in our first regression. The data on savings for some ethnic groups is not available until 2000 , so while the descriptive statistics are shown for all groups initially considered, the regression analysis is restricted to those groups for which we have full coverage over the timeframe $1994-2008^{5}$. We run the first regression on savers and nonsavers, while the second regression is run only on the sample of savers, defined as those respondents with at least one type of savings amongst basic accounts, national savings, saving for retirement and investments in any given year. We run two separate sets of regressions for men and women.

Only the results obtained from regressions where the coefficients are significant are reported here, results on full sample are also available on request. The following ethnic minority groups were excluded owing to insufficient number of observations on private savings: Any Other Asian, Black Caribbean, Black African, Any Other Black and Chinese.

Table 2 reports summary statistics on age, year of birth and total weekly income of our sample of savers.

[Insert Table 2 here]

other course.

${ }^{4}$ For the 'Year of Birth' variable the year of birth of the oldest respondent in the sample is taken as value of reference.

${ }^{5}$ The ethnic groups on which we run the regressions are: Indian, Pakistani, Bangladeshi and the control group. 
The age variable is expressed as deviations from 50 , while the year of birth is expressed as deviations from 1890, the year of birth of the oldest respondent in our sample (please see Jappelli, 1999). The average and median age is far lower for respondents of ethnic origins than for the white population, with Pakistani men and Indian women being the youngest in the sample. This may reveal an age bias and can be explained partially by greater longevity of the white population but also, importantly, by the tendency of some groups to move back to their country of origin after retirement.

Respondents belonging to the control group show higher levels of income than ethnic minority groups ( $£ 329$ and $£ 249$ per week, average and median values respectively for white men and $£ 170$ and $£ 128$ per week average and median values for white women). Mean income values of ethnic respondents range between $£ 276, £ 279$ and £297 per week for Pakistani, Indian and Bangladeshi men respectively, while median incomes are $£ 194, £ £ 191$ and $£ 215$ for the same groups. For women average weekly incomes vary between $£ 129$, $£ 148$ and $£ 162$ for Indian, Pakistani and Bangladeshi respectively, with much lower median values of $£ 77, £ 96$ and $£ 126$ for the same groups.

\section{Results}

The results of the first regression are illustrated in Tables 3 and 4 and show how saving participation ratios change over the life course for men and women separately ${ }^{6}$.

[Insert Table 3 here]

[Insert Table 4 here]

\footnotetext{
${ }^{6}$ The same regression was also run for each saving type independently but these results are not reported here for brevity, however they are available upon request.
} 
Tables 3 and 4 show a double set of results; in columns (1), (4), (7) and (10) we regress the probability to save on a fifth order age polynomial, without the sociodemographic controls, this represents the life-cycle model, while in columns (2), (5), (8) and (11) we run the regression including socio-economic control variables used in Jappelli (1999) as well as in Ginn and Arber (2001). Lastly, columns (3), (6), (9) and (12) include further control variables that were found to be significant determinants of saving and investments by Becker and Dimpfl (2016), Bertocchi et al. (2011) as well as Guiso et al. (2004). The number of children, marital status and social class were therefore added to improve the robustness of our initial model. The inclusion of the first set of socio-economic variables in our regression shows that full time work has a crucial effect on the likelihood to save across all groups. Although Bangladeshi men are less likely to be in full time work than other ethnic groups, those who are, display an increase of $17 \%$ in the probability to save, compared to $16 \%$ for the control group. The effect of full time employment on the likelihood to save is positive but weaker for Indian men at $7.3 \%$. For Pakistani men and women the results are not statistically significant. Results for female respondents are similar, for all ethnic groups, with the likelihood to save amongst those in full time employment being far greater than when working part-time, especially for white and Indian women, $15.4 \%$ and $13.2 \%$ respectively, and nearly $8 \%$ for Bangladeshi women. It is important to note that overall Bangladeshi women show a greater disadvantage in the work environment, with a very low participation ratio in full time employment throughout their life course thus affecting their saving participation rates. However the results so far show that full time employment is a key factor in explaining the decision to save across all groups examined.

Education has a noticeable effect on saving participation ratios. The coefficient for the dummy 'High Education' is positive and significant for all groups. Interestingly, high levels of education have a considerably greater impact on saving rates amongst ethnic groups than within the control group, for both the male and female samples. Specifically, Pakistani men and Bangladeshi women display higher correlation between education and saving rates. This can be explained, to some extent, by a greater awareness that 
respondents from these groups may hold of financial difficulties that can be caused by low education ${ }^{7}$.

The analysis on income shows that coefficients are statistically significant only for the control group, for both the male and female samples. The negative sign of the income coefficients and the positive sign of the squared income indicate a hump-shaped income curve, implying that those in the middle income levels save the most.

Our enhanced model shows that for the male sample, number of children is significant only for the white group, for which an additional child in the family reduces the probability to save by nearly $6 \%$, while for the same group belonging to high social class has a positive, significant effect on the probability to save of $6.5 \%$ and by a similar extent $(6.6 \%)$ on Bangladeshi men. The number of children is a significant determinant of saving for white women, who see their probability to save reduce by nearly $5 \%(4.8 \%)$ for each additional child in the family. Being single has an important negative effect on saving for white $(-5 \%)$ and, even more so, for Pakistani (-14\%) women. This large negative effect can be explained with the additional costs of living that individuals must sustain when living on their own, which, in the case of Pakistani women is amplified by the greater proportions of those in part time and low paid work. Social class has a very powerful positive effect on most ethnic female groups except Bangladeshi (for which is not significant), with a coefficient representing respectively an increase of nearly $24 \%$ and over $12 \%$ in the probability to save if belonging to a high social class for Indian and Pakistani women, compared to nearly $7 \%$ for the control group. These results reveal the highly significant explanatory power of ethnicity with gender and social class in the analysis of long term saving. The findings from our extended model also support the importance of employment and education for all groups examined.

In Figures $1 \mathrm{a}$ and $1 \mathrm{~b}$ we plot the results for men and women to show the saving

\footnotetext{
${ }^{7}$ The results presented here may also be affected by an unquantifiable bias due to a greater number of educated respondents amongst some ethnic groups.
} 
participation ratios of ethnic groups over their life course.

\author{
[Insert Figure 1a here]
}

[Insert Figure 1b here]

The data shows that when we control for socio-economic factors, Pakistani men display the highest propensity to save over their life course, although it declines sharply early in life (at the age of 30 ) and levels off after retirement. High self-employment rates, large families and alternative saving vehicles can help explain the saving patterns of Pakistani men. The saving participation ratio for Indian men is lower than that of the control group but follows a similar trend with both groups showing the highest probability to save between the ages of 35 and 50 . The data shows that Indian men tend to experience a small increase in their saving participation ratio in later life, which cannot be explained by the life-cycle theory. This in part could be based on the realisation that they are living longer and therefore they need to make provisions for an extended old age. Bangladeshi men, like Pakistanis, display a higher propensity to save up to the age of 35 , after which their saving participation declines and, by the age of 65 , becomes the lowest amongst the ethnic groups examined. This may be explained with their higher propensity in investing in a family business, property or in their children's education.

Figure $1 \mathrm{~b}$ indicates that, controlling for socio-economic status, the saving participation ratios for Pakistani $^{8}$ women are similar to those of the control group. Indian women also follow a similar pattern, although their likelihood to save over their life is constantly lower than for the control group. With the exception of Bangladeshi women, saving participation rates remain constant over time, however while women in the control

\footnotetext{
${ }^{8}$ The graph for Pakistani and Indian women stops at the age of 70 due to the small number of observations after that age
} 
group are most likely to save between the age of 30 and 45, Indian and Pakistani women's propensity to save increases even in their later years. This concurs with the general sentiment especially amongst the middle-aged female population, who have been unable to save enough during their working life, and therefore have a greater need to save for retirement later in life. Bangladeshi women show rapidly declining saving participation ratios, especially after the age of 40 . The disadvantage they experience in the workplace, with low probability of being in full time employment, together with larger families, affects their propensity and ability to save throughout their life.

Next we examine the levels of saving, using separate equations for males and females. The results are shown in tables 5 and 6 .

\author{
[Insert Table 5 here] \\ [Insert Table 6 here]
}

The outcomes of the basic regression on the age polynomial are displayed in columns (1), (4), (7) and (10), the results of a regression where an initial set of socioeconomic control variables are added are shown in columns (2), (5), (8) and (11) while the results of an enhanced regression model including additional control variables are displayed in columns (3), (6), (9) and (12).

Results show that education is a key positive determinant of the levels of saving but only for the control group. The number of children has again significant explanatory power for saving levels, where the high negative values of the coefficients show the very large impact of this variable on the amounts saved by women of all ethnicities, but especially by Indian and Bangladeshi women.

Education is statistically significant only for the control group and indicates that higher education increases saving accumulation by 8.3 per cent. Although the coefficient is not significant, the regression indicates a positive effect on saving accumulation amongst 
ethnic minority men. The results remain unchanged when using the enhanced model with added socio-economic variables. This is not surprising, especially within younger generations, as they are more likely to come from disadvantaged backgrounds than the control group and may have had some experience of financial difficulty and hence more prone to saving. Cultural attitudes to savings along with an emphasis on higher education therefore might help explain why educated Asian men show higher saving levels. It should be noted, however, that the percentages of those with higher levels of education and full time employment are quite low, particularly among Bangladeshis and Pakistanis. None of the coefficients on employment status are statistically significant.

The data on women indicates that for all ethnic groups, including the control group, income levels have a significant and positive effect on how much people save. The income coefficients are positive across all groups, but for ethnic minority women (Indian, Pakistani and Bangladeshi), the income levels are a greater determinant of their savings. The data reveals that Asian women save more than white women on similar income levels. The coefficients on employment status are not statistically significant for any of the ethnic groups examined, while education is statistically significant only for the control group, increasing their saving accumulation by 36.8 percent. Being single has a strong significant and positive effect on saving levels for both men and women of all ethnicities, which indicates that amongst those who do save, individuals who are not married are able and willing to save the most. Social class, is a significant and positive determinant of how much individuals save, its effect is strongest for Pakistani men and Bangladeshi women. This may be due to specificities within these cultures, whereby those of Asian origins may have been raised in environments where saving for their children and extended family is perceived to be a moral duty whenever possible.

Figures $2 \mathrm{a}$ and $2 \mathrm{~b}$ illustrate the saving profiles for ethnic groups plotted against age, for men and women separately.

[Insert Figure 2a here] 
[Insert Figure 2b here]

The coefficients for the age polynomial indicate that for Indian men the saving pattern follows the hump-shaped curve typical of the life-cycle model, with the accumulation of saving reaching the highest values between the ages of 45 and 50 . The data shows a steep fall in the amounts saved by Indian men after 50 and especially around the normal retirement age of 65 . This is in line with the theoretical framework of the life-cycle but it markedly indicates the exposure to a fast saving de-cumulation which can lead to poverty owing to inadequate retirement provisions made during the working life. Pakistani ${ }^{9}$ men display higher savings in the early stages of their life followed by considerable dis-saving around the age of 55 . This can be attributed, at least in part, to investment into a family business or self-employment, marriage and children. The saving profile of Bangladeshi men shows a stable upward trend over the life course. The steady increase in savings in later years could be a consequence of high self-employment rates and cultural factors, for example building up financial wealth to pass on to their children.

The saving profiles of women indicate that ethnic minorities tend to have lower saving ratios than the control group over their whole life cycle. Saving accumulation for Indian women remains stable in their young age before declining relatively early in life, with a large drop in savings around the age of 45 and negative saving accumulation after the age of 55. For Bangladeshi women savings decline slowly but steadily over their life course, while Pakistani women display stable saving accumulation ratios over their working lives and beyond. The low but stable levels of savings amongst Bangladeshi and Pakistani women may result from the higher probability of being in part-time jobs ${ }^{10}$. The abrupt decline in

\footnotetext{
${ }^{9}$ The graph for Pakistani men stops at the age of 70 , owing to the small number of observations after that age.

${ }^{10}$ Some results for Pakistani and Bangladeshi women are not statistically significant, therefore their
} 
saving accumulation experienced by Indian women early in life could be attributed to the sharp reduction in their employment rates after the age of 50 . This can be attributed to the widespread trend, amongst Asian women, of retiring early to look after grandchildren or other members of their extended family.

\section{Conclusions}

We examine life-long saving arrangements in the UK by applying the life-cycle framework. Our empirical analysis adds an important dimension to the debate on long-term saving by testing for the effects of socio-economic factors on saving decisions of ethnic groups during different phases of their life. By merging consecutive waves of the Family Resource Survey, we were able to obtain a dataset rich with information on ethnic minorities and so overcome the issue of small samples.

We show that employment, educational background, income and social class are significant factors in determining how individuals plan and prepare for retirement. The disadvantage in terms of employment suffered by some ethnic groups is instrumental to their inability to save on a long-term basis. Particularly, the disadvantage suffered in the workplace by Pakistani and Bangladeshi women is still very high, however our findings also show that women belonging to Asian ethnic groups, with good education and social standing display greater saving rates than the control group.

Importantly, the differences between ethnic minorities and the white population decrease significantly once we control for variables that are highly correlated to the probability of saving, such as employment status, education, number of children, marital status and social class. These results are at odds with the perceived cultural barriers and inter-generational support which have been advocated to explain lower savings in the past and may be instrumental in explaining higher levels of poverty in old age amongst some ethnic groups. In other words high levels of poverty in old age are more likely to be caused

statistical analysis remains somewhat limited. 
by the interaction of factors such as low levels of education, high proportions of part time work and unemployment as well as high number of children which are more often, but not exclusively, associated with some ethnic groups.

Our life-cycle analysis shows that white men tend to accumulate savings more smoothly over their life than most ethnic men, particularly Pakistani, for whom saving decumulation starts very early in life. The hump-shaped curve of saving accumulation displayed by Indian men is in agreement with the life-cycle model, but also shows evidence of the high risks of falling into poverty around and after retirement age when dis-saving becomes significant.

We find strong empirical evidence that ethnic women are less likely to save than their white counterparts and display trends of substantial saving de-cumulation very early in life, particularly, the lack of long-term savings shown by women of Bangladeshi and Pakistani origins is of concern. This appears to stem from the financial disadvantage they experience during their working lives and is likely to lead them into poverty after retirement. These results are in line with previous studies (Ginn and Arber, 2001; Blackaby et al., 2005), reinforcing the significance of the link between the disadvantage experienced in terms of education and employment by specific groups and lower levels of long-term savings.

Private savings are becoming an increasingly important source of retirement income and our research indicates that, in the UK, there are still differences in saving levels between the white majority and ethnic groups. The financial disadvantage that starts with the employment status is an issue that affects those of Pakistani and Bangladeshi origins more than others and is likely to be perpetuated and exacerbated in the years to come unless adequately addressed. Although most ethnic groups show a positive propensity towards saving at the start of their working lives, overall, our research shows that the culmination of a life-long disadvantage has a significant effect on their ability to save long-term and closer to retirement. 


\section{References}

Agree, E. M., Biddlecom, A. E., and Valente, T. W. (2005) "Intergenerational transfers of resources between older persons and extended kin in Taiwan and the Philippines", Population Studies, Vol. 59 No. 2, pp. 181-195

Alessie, R., Lusardi, A., and Aldershof, T. (1997) "Income and wealth over the life cycle: evidence from panel data", Review of Income and Wealth, Vol. 43 No. 1, pp. 1-32.

Ando A. and Modigliani, F. (1963) "The 'Life Cycle' hypothesis of saving: aggregate implications and tests", American Economic Review, Vol. 53 No. 1, pp. 55-84.

Balli, F., Pericoli, F.M. and Pierucci, E. (2016) "Channels of Risk Sharing at Micro Level: Savings, Investments and Risk Aversion Heterogeneity", International Journal of Finance and Economics, Vol. 21 No. 1, pp. 90-104.

Banks, J., Blundell, R. and Tanner, S. (1998) "Is there a retirement-savings puzzle?" American Economic Review, Vol. 88 No. 4, pp. 769-788.

Barr, N. and Diamond, P. (2008) Reforming Pensions: Principles and Policy Choices, Oxford University Press, Oxford.

Battu, H. and Zenou, Y. (2010) "Oppositional identities and employment for ethnic minorities: evidence from England", Economic Journal, Vol. 120 No. 542, pp. F52-F71.

Bauer, T. and Zimmermann, K.F. (1997) “Unemployment and wages of ethnic Germans", The Quarterly Review of Economics and Finance, Vol. 37 Supplement 1 pp. 361-377.

Becker, G. and Dimpfl, T. (2016) "Labor income risk and households' risky asset holdings", Studies in Economics and Finance, Vol. 33 No. 2, pp. 262-280

Berthoud, R. (2000) “Ethnic employment penalties in Britain”, Journal of Ethnic and Migration Studies, Vol. 26 No. 3, pp. 389-416.

Bertocchi, G., Brunetti, M. and Torricelli, C. (2011) "Marriage and other risky assets: a portfolio approach", Journal of Banking and Finance, Vol. 35 No. 11, pp. 2902-2915.

Blackaby, D., Drinkwater, S., Leslie, D. and Murphy, P. (1997) “A picture of male and female unemployment among Britain's ethnic minorities", Scottish Journal of Political Economy, Vol. 44 No. 2, pp. 182-97. 
Blackaby, D., Leslie, D., Murphy, P. and O'Leary, N.C. (2002) “White/Ethnic minority earnings and employment differentials in Britain: evidence from the LFS" Oxford Economic Papers, Vol. 54 No. 2, pp. 270-297.

Blackaby, D, D. G .Leslie, P.D. Murphy and O'Leary, N.C. (2005) "Born in Britain: how are the native ethnic minorities faring in the British labour market?" Economic Letters, Vol. 88 No. 3, pp. 370-375.

Blau, D.M. (2008) "Retirement and consumption in a life cycle model", Journal of Labor Economics, Vol. 26 No. 1, pp. 35-71.

Börsch-Supan, A., Brugiavini, A., Croda, E. (2009) "The role of institutions and health in European patterns of work and retirement" Journal of European Social Policy, Vol. 19 No. 4, pp. 341-358.

Bradley, H., Healy, G. and Kaul, P. (2007) Ethnic Minority Women and Workplace Cultures: What does and does not work. Manchester, EOC.

Bradley, H. and Healy, G. (2008) Ethnicity and Gender at Work. Inequalities, Careers and Employment Relations, Palgrave Macmillan, New York.

Browning, M. and Crossley, T.F. (2001) "The life-cycle model of consumption and saving", Journal of Economic Perspectives, Vol. 15 No. 3, pp. 3-22.

Browning, M. and Lusardi, A. (1996) "Household savings: micro theories and micro facts", Journal of Economic Literature, Vol. 34 No. 4, pp. 1797-1855.

Cabinet Office (2003) "Ethnic Minorities and the Labour Market: Final Report" Strategy Unit, London.

Chetty, R., Friedman, J. N., Leth-Petersen, S. T., Nielsen, H. and Olsen, T. (2014) "Active Vs. Passive Decisions and Crowd-Out in Retirement Savings Accounts: Evidence from Denmark." The Quarterly Journal of Economics, Vol. 129 No. 3, pp. 1141-1219.

Clark, K and Drinkwater, S. (2000) "Pushed out or pulled in? Self-employment among ethnic minorities in England and Wales", Labour Economics, Vol. 7 No. 5, pp. 603-628.

Crossan, D., Feslier, D. and Hurnard, R. (2011) "Financial literacy and retirement planning in New Zealand", Journal of Pension Economics and Finance, Vol. 10 No. 4, pp. 619- 
635.

Cuong, N.V., Tung, P.D., Westbrook, D. (2015) "Do the poorest ethnic minorities benefit from a large-scale poverty reduction program? Evidence from Vietnam" The Quarterly Review of Economics and Finance, Vol. 56 May Issue, pp. 3-14.

Dale, A., Lindley, J. K. and Dex, S. (2006) "A life course perspective on ethnic differences in women's economic activity in Britain”, European Sociological Review, Vol. 22 No. 3, pp. $459-476$.

Feldmann, H. (2013) "Financial System Sophistication and Unemployment in Industrial Countries", International Journal of Finance and Economics, Vol. 18 No. 4, pp. 319338.

Frankenberg, E., Lillard, L. and Willis, R. J. (2002), Patterns of Intergenerational Transfers in Southeast Asia. Journal of Marriage and Family, Vol. 64 No. 3, pp. 627-641

Friedman, M. A. (1957) Theory of the Consumption Function. Princeton University Press for NBER.

Ginn, J. and Arber, S. (2001) "Pension prospects of minority ethnic groups: inequalities by gender and ethnicity", British Journal of Sociology, Vol. 52 No. 3, pp. 519-539.

Gough, O. and Adami, R. (2013) "Saving for retirement: a review of ethnic minorities in the UK", Social Policy and Society, Vol. 12 No. 1, pp. 147-161.

Guiso, L., Haliassos, M. and Jappelli, T. (2003) "Household stockholding in Europe: where do we stand and where do we go?" Economic Policy, Vol. 18 No. 36, pp. 123-170.

Guiso, L., Sapienza, P. and Zingales, L. (2004) "The role of social capital in financial development" The American Economic Review, Vol. 94 No. 3, pp. 526-556

Han, C-K. and Sherraden, M. (2009) "Do institutions really matter for saving among lowincome households? A comparative approach", Journal of Socio-Economics, Vol. 38 No. 3, pp. $475-483$.

Hoque, K. and Noon, M. (2004) "Equal opportunities policies and practice in Britain: evaluating the 'empty shell' hypothesis", Work, Employment and Society, Vol. 18 No. 3, pp. 481-506. 
Jappelli, T. (1999) "The age-wealth profile and the life-cycle hypothesis: a cohort analysis with a time series of cross-sections of Italian households", Review of Income and Wealth, Vol. 45 No. 1, pp. 57-75.

Jappelli, T. (2005) "The Life-Cycle Hypothesis, Fiscal Policy, and Social Security", BNL Quarterly Review, Vol. 58 June-September Issue, pp. 233-243.

Johnson, P. (2004) "Long term historical changes in the status of elders: the United Kingdom as an exemplar of advanced industrial countries", in Lloyd-Sherlock, P. (ed.), Living Longer: Ageing, Development and Social Protection, Zed Books: New York, NY.

Kandil, M. (2015) "Determinants of Lower Saving Rates in the USA: Prospects and Implications", International Journal of Finance and Economics, Vol. 20 No. 4, pp. $328-340$.

Kempson, E. (1998) Savings and Ethnic Minority Households. Personal Investment Authority Research Reports, London: Personal Investments Authority.

Khan, O. (2010) "Saving Beyond the High Street: A Profile of Saving Patterns among Black and Minority Ethnic People". Runnymede Trust.

Larsen, C.A., Dejgaard, T.E. (2013) "The institutional logic of images of the poor and welfare recipients: A comparative study of British, Swedish and Danish newspapers" Journal of European Social Policy, Vol. 23 No. 3, pp. 287-299.

Lewis, C.M., Lloyd-Sherlock, P. (2009) "Social policy and economic development in South America: an historical approach to social insurance", Economy and Society, Vol. 38 No. 1, pp. 109-131.

Lianos, T.P., Asteriou, D. and Agiomirgianakis, G. M. (2004) "Foreign university graduates in the Greek labour market: Employment, salaries and overeducation", International Journal of Finance and Economics, Vol. 9 No. 2, pp. 151-164.

Lindley, J.K., Dale, A. and Dex, S. (2006) "Ethnic differences in women's employment: the changing role of qualifications", Oxford Economic Papers, Vol. 58 No. 2, pp. 351-378.

Lindsey, D. A. (1998) "Attitudes on race, culture and discrimination in mortgage lending", Studies in Economics and Finance, Vol. 19 No. 1/2, pp.48-76 
Lusardi, A. and Mitchell, O.S. (2007) "Baby boomer retirement security: the roles of planning, financial literacy, and housing wealth", Journal of Monetary Economics, Vol. 54 No. 1, pp. 205-24.

Lusardi, A., Mitchell, O.S. (2011a) "Financial literacy and retirement planning in the United States", Journal of Pension Economics and Finance, Vol. 10 No. 4, pp. 509-525.

Lusardi, A., Mitchell, O.S. (2011b) "Financial literacy around the world: an overview", Journal of Pension Economics and Finance, Vol. 10, No. 4 pp. 497-508.

Lusardi, A., Mitchell, O.S. and Curto, V. (2012) "Financial Sophistication in the Older Population", PRC WP2012-01 Pension Research Council Working Paper.

Malveaux, J. (1999) "Women of color in the labor market", The Quarterly Review of Economics and Finance, Vol. 39 No. 5, pp. 663-678.

Mastrogiacomo, M. and Alessie, R. (2014) "The precautionary savings motive and household savings", Oxford Economic Papers, Vol. 66 No. 1, pp. 164 - 187.

Mitchell, O.S., Lusardi, A. (2011) "Financial Literacy: Implications for Retirement Security and the Financial Marketplace". OUP Oxford.

Modigliani, F. and Brumberg, R. (1954) "Utility analysis and the consumption function: an interpretation of cross-section data", in Post-Keynesian Economics. Kurihara, R, ed. New Brunswick: Rutgers University Press, pp. 388-436.

Modood, T., Berthoud, R., Lakey, J., Nazroo, J., Smith, P., Virdee, S., and Beishon, S. (1997) Ethnic Minorities in Britain: Diversity and Disadvantage, Policy Studies Institute, London.

Nesbitt, S. and Neary, D. (2001) Ethnic Minorities and their Pension Decisions'. Joseph Rowntree Foundation.

Office of National Statistics (2006) Focus on Ethnicity and Religion. Palgrave Macmillan, Hampshire.

Patrinos, H.A., (1997) "Differences in education and earnings across ethnic groups in Guatemala", The Quarterly Review of Economics and Finance, Vol. 37 No. 4, pp. $809-821$. 
Pensions Policy Institute (2003) The Under-Pensioned: Non Standard Employment, London.

Ramji, H. (2006) "British Indians returning home: an exploration of transnational belongings", Sociology, Vol. 40 No. 4, pp. 645-662.

Russo, B., Gandar, J.M. (2003) "Interest-sensitive wealth and the life-cycle hypothesis: implications for fiscal policy", The Quarterly Review of Economics and Finance, Vol. 43 No. 3, pp. 418-432.

Salway, S. (2006) Economic activity among UK Bangladeshi and Pakistani women in 1990s: evidence for continuity or change in the Family Resources Survey? Journal of Ethnic and Migration Studies, Vol. 33 No. 5, pp. 825-847

Salway, S., L. Platt, P. Chowbey, K. Harriss and Bayliss, E. (2007) Long-Term III-Health, Poverty and Ethnicity. The Policy Press: Bristol.

Seto, S., Bogan, V.L. (2013) "Immigrant Household Investment Behavior and Country of Origin: A Study of Immigrants to the United States", International Journal of Finance and Economics, Vol. 18 No. 2, pp. 128-158.

Smith, S. (2006) "The retirement-consumption puzzle and involuntary early retirement: evidence from the British Household Panel Survey", Economic Journal, Vol. 116 No. 510, pp. $130-148$

Steventon, A. and Sanchez, C. (2008) The Under-Pensioned: Disabled People and People from Ethnic Minorities. EHRC Research Report 5, London: EHRC.

Tavor, T. and Garyn-Tal, S. (2016) "Risk tolerance and rationality in the case of retirement savings", Studies in Economics and Finance, Vol. 33 No. 4, pp. 688703

Van Rooij, M.C.J., Lusardi, A. and Alessie, R. (2012) “Financial literacy, retirement planning and household wealth", Economic Journal, Vol. 122 No. 560, pp. 449-478

Vlachantoni, A., Feng, Z., Evandrou, M. and Falkingham, J. (2017) "Ethnic elders and pension protection in the United Kingdom", Ageing \& Society, Vol. 37, No. 5, pp. $1025-1049$ 
Warnes, A.M., Friedrich, K., Kellaher, L., and Torres, S. (2004) "The diversity and welfare of older migrants in Europe", Aging and Society, Vol. 24 No. 3, pp. 307-326.

Winter, J.K., Schlafmann, K. and Rodepeter, R. (2012) "Rules of thumb in life-cycle saving decisions", Economic Journal, Vol. 122 No. 560, pp. 479-501. 
Table 1. Sample according to age, gender, ethnic background, employment status (\%).

\begin{tabular}{|c|c|c|c|c|c|c|c|c|c|c|c|}
\hline & 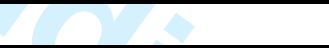 & WHITE & Indian & Pakistani & Bangladeshi & AO Asian & Black Caribbean & Black African & AO Black & Chinese & All \\
\hline MEN & $\mathbf{N}$ & 296,282 & 3,073 & 1,823 & 2,168 & 700 & 1,276 & 1,058 & 86 & 424 & 306,890 \\
\hline \multirow[t]{6}{*}{ Age 16 to 24} & FT Self Employed & $3.0 \%$ & $0.7 \%$ & $1.2 \%$ & $0.6 \%$ & $1.4 \%$ & $0.7 \%$ & $0.0 \%$ & $0.0 \%$ & $0.0 \%$ & $2.9 \%$ \\
\hline & FT Employed & $56.8 \%$ & $33.3 \%$ & $24.1 \%$ & $27.6 \%$ & $21.1 \%$ & $33.1 \%$ & $17.9 \%$ & $14.3 \%$ & $16.0 \%$ & $55.2 \%$ \\
\hline & PT or Self Employed & $9.6 \%$ & $17.6 \%$ & $20.4 \%$ & $13.3 \%$ & $22.5 \%$ & $14.1 \%$ & $20.1 \%$ & $0.0 \%$ & $17.9 \%$ & $10.0 \%$ \\
\hline & Unemployed & $15.1 \%$ & $12.1 \%$ & $11.1 \%$ & $17.1 \%$ & $12.7 \%$ & $20.4 \%$ & $18.7 \%$ & $28.6 \%$ & $5.7 \%$ & $15.0 \%$ \\
\hline & Not Working for AOR & $15.5 \%$ & $36.3 \%$ & $43.2 \%$ & $41.4 \%$ & $42.3 \%$ & $31.7 \%$ & $43.3 \%$ & $57.1 \%$ & $60.4 \%$ & $16.9 \%$ \\
\hline & $\mathbf{N}$ & 28,269 & 421 & 324 & 362 & 71 & 142 & 134 & 7 & 106 & 29,836 \\
\hline \multirow[t]{6}{*}{ Age 25 to 34} & FT Self Employed & $8.6 \%$ & $6.7 \%$ & $14.2 \%$ & $6.9 \%$ & $6.9 \%$ & $4.3 \%$ & $2.7 \%$ & $7.7 \%$ & $8.4 \%$ & $8.5 \%$ \\
\hline & FT Employed & $73.3 \%$ & $68.3 \%$ & $46.0 \%$ & $43.9 \%$ & $53.7 \%$ & $59.7 \%$ & $55.8 \%$ & $65.4 \%$ & $55.1 \%$ & $72.4 \%$ \\
\hline & PT or Self Employed & $4.1 \%$ & $10.0 \%$ & $17.3 \%$ & $13.2 \%$ & $12.4 \%$ & $5.9 \%$ & $15.0 \%$ & $3.8 \%$ & $12.1 \%$ & $4.6 \%$ \\
\hline & Unemployed & $6.8 \%$ & $6.3 \%$ & $9.6 \%$ & $16.1 \%$ & $6.4 \%$ & $12.9 \%$ & $9.2 \%$ & $0.0 \%$ & $5.6 \%$ & $6.9 \%$ \\
\hline & Not Working for AOR & $7.2 \%$ & $8.7 \%$ & $13.1 \%$ & $19.8 \%$ & $20.6 \%$ & $17.2 \%$ & $17.3 \%$ & $23.1 \%$ & $18.7 \%$ & $7.6 \%$ \\
\hline & $\mathbf{N}$ & 50,245 & 760 & 544 & 620 & 218 & 186 & 294 & 26 & 107 & 53,000 \\
\hline \multirow[t]{6}{*}{ Age 35 to 44} & FT Self Employed & $11.8 \%$ & $13.2 \%$ & $21.7 \%$ & $10.0 \%$ & $10.8 \%$ & $8.3 \%$ & $10.4 \%$ & $0.0 \%$ & $12.2 \%$ & $11.9 \%$ \\
\hline & FT Employed & $71.2 \%$ & $61.7 \%$ & $44.8 \%$ & $49.9 \%$ & $56.2 \%$ & $65.6 \%$ & $56.1 \%$ & $61.3 \%$ & $68.9 \%$ & $70.5 \%$ \\
\hline & PT or Self Employed & $4.1 \%$ & $10.7 \%$ & $13.7 \%$ & $13.2 \%$ & $13.5 \%$ & $3.9 \%$ & $8.6 \%$ & $19.4 \%$ & $10.0 \%$ & $4.4 \%$ \\
\hline & Unemployed & $4.7 \%$ & $5.8 \%$ & $8.7 \%$ & $10.5 \%$ & $4.3 \%$ & $9.2 \%$ & $11.0 \%$ & $9.7 \%$ & $1.1 \%$ & $4.8 \%$ \\
\hline & Not Working for AOR & $8.2 \%$ & $8.5 \%$ & $11.1 \%$ & $16.4 \%$ & $15.1 \%$ & $13.1 \%$ & $13.9 \%$ & $9.7 \%$ & $7.8 \%$ & $8.4 \%$ \\
\hline & $\mathbf{N}$ & 56,917 & 726 & 415 & 561 & 185 & 360 & 374 & 31 & 90 & 59,659 \\
\hline \multirow{6}{*}{ Age 45 to 54} & FT Self Employed & $12.9 \%$ & $17.1 \%$ & $24.1 \%$ & $12.9 \%$ & $14.2 \%$ & $10.6 \%$ & $9.1 \%$ & $18.2 \%$ & $30.9 \%$ & $13.0 \%$ \\
\hline & FT Employed & $64.6 \%$ & $52.7 \%$ & $31.1 \%$ & $49.1 \%$ & $55.1 \%$ & $62.8 \%$ & $63.6 \%$ & $54.5 \%$ & $47.1 \%$ & $64.1 \%$ \\
\hline & PT or Self Employed & $5.1 \%$ & $5.6 \%$ & $15.6 \%$ & $8.8 \%$ & $6.3 \%$ & $4.4 \%$ & $6.7 \%$ & $0.0 \%$ & $4.4 \%$ & $5.2 \%$ \\
\hline & Unemployed & $4.6 \%$ & $6.0 \%$ & $8.6 \%$ & $7.9 \%$ & $7.9 \%$ & $8.9 \%$ & $7.3 \%$ & $18.2 \%$ & $2.9 \%$ & $4.6 \%$ \\
\hline & Not Working for AOR & $12.9 \%$ & $18.5 \%$ & $20.6 \%$ & $21.4 \%$ & $16.5 \%$ & $13.3 \%$ & $13.3 \%$ & $9.1 \%$ & $14.7 \%$ & $13.0 \%$ \\
\hline & $\mathbf{N}$ & 52,525 & 514 & 257 & 318 & 127 & 180 & 165 & 11 & 68 & 54,165 \\
\hline \multirow[t]{6}{*}{ Age 55 to 64} & FT Self Employed & $9.8 \%$ & $12.5 \%$ & $8.6 \%$ & $5.3 \%$ & $7.0 \%$ & $10.6 \%$ & $6.0 \%$ & $0.0 \%$ & $10.3 \%$ & $9.8 \%$ \\
\hline & FT Employed & $38.8 \%$ & $30.1 \%$ & $15.7 \%$ & $31.2 \%$ & $54.4 \%$ & $40.4 \%$ & $52.0 \%$ & $0.0 \%$ & $41.4 \%$ & $38.7 \%$ \\
\hline & PT or Self Employed & $8.5 \%$ & $5.8 \%$ & $10.0 \%$ & $8.8 \%$ & $8.8 \%$ & $4.3 \%$ & $6.0 \%$ & $0.0 \%$ & $10.3 \%$ & $8.5 \%$ \\
\hline & Unemployed & $4.1 \%$ & $4.6 \%$ & $12.1 \%$ & $5.9 \%$ & $1.8 \%$ & $4.3 \%$ & $8.0 \%$ & $25.0 \%$ & $13.8 \%$ & $4.1 \%$ \\
\hline & Not Working for AOR & $38.8 \%$ & $47.1 \%$ & $53.6 \%$ & $48.8 \%$ & $28.1 \%$ & $40.4 \%$ & $28.0 \%$ & $75.0 \%$ & $24.1 \%$ & $38.9 \%$ \\
\hline & $\mathbf{N}$ & 46,219 & 329 & 140 & 170 & 57 & 141 & 50 & 4 & 29 & 47,139 \\
\hline
\end{tabular}




\section{Table 1 - Continued}

\begin{tabular}{|c|c|c|c|c|c|c|c|c|c|c|c|}
\hline & $\Delta$ & WHITE & Indian & Pakistani & Bangladeshi & AO Asian & Black Caribbean & Black African & AO Black & Chinese & All \\
\hline WOMEN & $\mathbf{N}$ & 333,974 & 3,223 & 1,995 & 2,543 & 872 & 1,665 & 1,357 & 123 & 546 & 346,298 \\
\hline \multirow[t]{6}{*}{ Age 16 to 24} & FT Self Employed & $0.6 \%$ & $0.4 \%$ & $0.6 \%$ & $0.0 \%$ & $0.0 \%$ & $0.6 \%$ & $0.0 \%$ & $0.0 \%$ & $0.0 \%$ & $0.6 \%$ \\
\hline & FT Employed & $44.4 \%$ & $26.6 \%$ & $14.9 \%$ & $18.6 \%$ & $21.6 \%$ & $22.0 \%$ & $16.1 \%$ & $23.8 \%$ & $12.4 \%$ & $42.9 \%$ \\
\hline & PT or Self Employed & $16.4 \%$ & $14.7 \%$ & $11.3 \%$ & $15.8 \%$ & $16.5 \%$ & $23.2 \%$ & $17.7 \%$ & $28.6 \%$ & $15.2 \%$ & $16.4 \%$ \\
\hline & Unemployed & $8.7 \%$ & $8.0 \%$ & $8.3 \%$ & $15.8 \%$ & $5.2 \%$ & $10.4 \%$ & $7.0 \%$ & $4.8 \%$ & $8.6 \%$ & $8.8 \%$ \\
\hline & Not Working for AOR & $29.9 \%$ & $50.2 \%$ & $65.0 \%$ & $49.8 \%$ & $56.7 \%$ & $43.9 \%$ & $59.1 \%$ & $42.9 \%$ & $63.8 \%$ & $31.3 \%$ \\
\hline & $\mathbf{N}$ & 30,288 & 462 & 363 & 442 & 97 & 164 & 186 & 21 & 105 & 32,128 \\
\hline \multirow{6}{*}{ Age 25 to 34} & FT Self Employed & $2.0 \%$ & $1.3 \%$ & $1.8 \%$ & $0.8 \%$ & $0.7 \%$ & $0.7 \%$ & $0.9 \%$ & $0.0 \%$ & $4.7 \%$ & $1.9 \%$ \\
\hline & FT Employed & $42.3 \%$ & $38.0 \%$ & $18.7 \%$ & $24.0 \%$ & $39.4 \%$ & $41.3 \%$ & $32.8 \%$ & $45.2 \%$ & $41.2 \%$ & $41.6 \%$ \\
\hline & PT or Self Employed & $22.1 \%$ & $13.2 \%$ & $11.8 \%$ & $12.9 \%$ & $13.5 \%$ & $21.0 \%$ & $15.7 \%$ & $12.9 \%$ & $14.9 \%$ & $21.6 \%$ \\
\hline & Unemployed & $4.2 \%$ & $5.1 \%$ & $4.0 \%$ & $6.8 \%$ & $3.8 \%$ & $5.0 \%$ & $4.8 \%$ & $6.5 \%$ & $0.7 \%$ & $4.3 \%$ \\
\hline & Not Working for AOR & $29.5 \%$ & $42.5 \%$ & $63.7 \%$ & $55.5 \%$ & $42.6 \%$ & $32.0 \%$ & $45.9 \%$ & $35.5 \%$ & $38.5 \%$ & $30.6 \%$ \\
\hline & $\mathbf{N}$ & 57,871 & 871 & 619 & 782 & 289 & 300 & 458 & 31 & 148 & 61,369 \\
\hline \multirow[t]{6}{*}{ Age 35 to 44} & FT Self Employed & $2.6 \%$ & $2.1 \%$ & $2.2 \%$ & $3.5 \%$ & $3.2 \%$ & $1.2 \%$ & $1.9 \%$ & $0.0 \%$ & $4.1 \%$ & $2.6 \%$ \\
\hline & FT Employed & $36.9 \%$ & $33.1 \%$ & $14.8 \%$ & $28.1 \%$ & $29.7 \%$ & $51.3 \%$ & $38.5 \%$ & $42.5 \%$ & $31.4 \%$ & $36.7 \%$ \\
\hline & PT or Self Employed & $32.0 \%$ & $20.4 \%$ & $13.3 \%$ & $13.5 \%$ & $23.3 \%$ & $22.7 \%$ & $15.2 \%$ & $17.5 \%$ & $17.4 \%$ & $31.3 \%$ \\
\hline & Unemployed & $3.2 \%$ & $2.9 \%$ & $1.7 \%$ & $5.0 \%$ & $3.7 \%$ & $3.4 \%$ & $4.3 \%$ & $7.5 \%$ & $2.5 \%$ & $3.3 \%$ \\
\hline & Not Working for AOR & $25.3 \%$ & $41.6 \%$ & $67.9 \%$ & $50.0 \%$ & $40.2 \%$ & $21.3 \%$ & $40.1 \%$ & $32.5 \%$ & $44.6 \%$ & $26.1 \%$ \\
\hline & $\mathbf{N}$ & 62,282 & 722 & 458 & 606 & 219 & 497 & 421 & 40 & 121 & 65,366 \\
\hline \multirow[t]{6}{*}{ Age 45 to 54} & FT Self Employed & $3.1 \%$ & $3.3 \%$ & $4.1 \%$ & $1.2 \%$ & $2.2 \%$ & $1.9 \%$ & $3.4 \%$ & $5.9 \%$ & $9.4 \%$ & $3.1 \%$ \\
\hline & FT Employed & $40.4 \%$ & $32.2 \%$ & $15.2 \%$ & $34.3 \%$ & $50.4 \%$ & $47.3 \%$ & $55.1 \%$ & $52.9 \%$ & $41.7 \%$ & $40.3 \%$ \\
\hline & PT or Self Employed & $28.5 \%$ & $21.5 \%$ & $11.5 \%$ & $12.2 \%$ & $20.0 \%$ & $20.5 \%$ & $18.2 \%$ & $11.8 \%$ & $19.8 \%$ & $28.1 \%$ \\
\hline & Unemployed & $2.6 \%$ & $2.3 \%$ & $4.7 \%$ & $6.4 \%$ & $2.2 \%$ & $5.7 \%$ & $3.4 \%$ & $5.9 \%$ & $4.2 \%$ & $2.7 \%$ \\
\hline & Not Working for AOR & $25.4 \%$ & $40.6 \%$ & $64.5 \%$ & $45.9 \%$ & $25.2 \%$ & $24.6 \%$ & $19.9 \%$ & $23.5 \%$ & $25.0 \%$ & $25.9 \%$ \\
\hline & $\mathbf{N}$ & 55,128 & 512 & 296 & 344 & 135 & 264 & 176 & 17 & 96 & 56,968 \\
\hline \multirow[t]{6}{*}{ Age 55 to 64} & FT Self Employed & $1.7 \%$ & $0.9 \%$ & $0.7 \%$ & $0.5 \%$ & $4.1 \%$ & $1.1 \%$ & $0.0 \%$ & $0.0 \%$ & $5.1 \%$ & $1.6 \%$ \\
\hline & FT Employed & $17.4 \%$ & $15.6 \%$ & $3.0 \%$ & $19.3 \%$ & $24.7 \%$ & $20.9 \%$ & $36.0 \%$ & $10.0 \%$ & $25.6 \%$ & $17.4 \%$ \\
\hline & PT or Self Employed & $20.5 \%$ & $9.1 \%$ & $6.0 \%$ & $7.9 \%$ & $21.9 \%$ & $13.2 \%$ & $10.7 \%$ & $0.0 \%$ & $15.4 \%$ & $20.3 \%$ \\
\hline & Unemployed & $1.2 \%$ & $2.1 \%$ & $1.5 \%$ & $2.0 \%$ & $2.7 \%$ & $1.1 \%$ & $1.3 \%$ & $0.0 \%$ & $5.1 \%$ & $1.2 \%$ \\
\hline & Not Working for AOR & $59.2 \%$ & $72.3 \%$ & $88.8 \%$ & $70.3 \%$ & $46.6 \%$ & $63.7 \%$ & $52.0 \%$ & $90.0 \%$ & $48.7 \%$ & $59.4 \%$ \\
\hline & $\mathbf{N}$ & 49,396 & 339 & 134 & 202 & 73 & 182 & 75 & 10 & 39 & 50,450 \\
\hline
\end{tabular}

Source: Family Resources Surveys 1994-2008 (authors' analysis) 
Table 2. Summary statistics of savers

\begin{tabular}{|c|c|c|c|c|c|}
\hline \multirow{2}{*}{$\bar{P}$} & & \multicolumn{2}{|c|}{ MALE } & \multicolumn{2}{|c|}{ FEMALE } \\
\hline & & Mean & Median & Mean & Median \\
\hline \multirow[t]{3}{*}{ WHITE } & AGE & -2.7 & -4.0 & -1.5 & -3.0 \\
\hline & YEAR-OF-BIRTH & 60.6 & 62.0 & 59.4 & 61.0 \\
\hline & TOTAL INCOME & 328.8 & 249.0 & 170.4 & 128.0 \\
\hline \multirow[t]{3}{*}{ Indian } & AGE & -8.88 & -12.00 & -11.72 & -15.00 \\
\hline & YEAR-OF-BIRTH & 68.41 & 72.00 & 71.32 & 74.00 \\
\hline & TOTAL INCOME & 279.18 & 190.50 & 128.95 & 76.50 \\
\hline \multirow[t]{3}{*}{ Pakistani } & AGE & -11.72 & -14.00 & -11.51 & -14.00 \\
\hline & YEAR-OF-BIRTH & 70.73 & 73.00 & 70.40 & 72.00 \\
\hline & TOTAL INCOME & 275.96 & 194.00 & 147.61 & 96.00 \\
\hline \multirow[t]{3}{*}{ Bangladeshi } & AGE & -11.18 & -13.00 & -11.19 & -14.00 \\
\hline & YEAR-OF-BIRTH & 69.01 & 72.00 & 69.10 & 72.00 \\
\hline & TOTAL INCOME & 297.26 & 215.00 & 162.35 & 126.00 \\
\hline
\end{tabular}

Source: Family Resources Surveys 1994-2008 (authors' analysis) 
Table 3. Regression results on the likelihood to save, male sample.

\begin{tabular}{|c|c|c|c|c|c|c|c|c|c|c|c|c|}
\hline \multirow{3}{*}{$\begin{array}{l}\text { Dependent Variable } \\
\text { Independent Variables }\end{array}$} & \multicolumn{3}{|c|}{ WHITE } & \multicolumn{3}{|c|}{ Indian } & \multicolumn{3}{|c|}{ Pakistani } & \multicolumn{3}{|c|}{ Bangladeshi } \\
\hline & \multicolumn{12}{|c|}{$\begin{array}{c}\text { TOTAL SAVINGS } D \\
\end{array}$} \\
\hline & (1) & (2) & (3) & (4) & (5) & (6) & (7) & (8) & (9) & (10) & (11) & (12) \\
\hline AGE & $\begin{array}{l}0.001 \\
(0.75)\end{array}$ & $\begin{array}{l}-0.000 \\
(-0.17)\end{array}$ & $\begin{array}{c}-0.002 * * \\
(-1.96)\end{array}$ & $\begin{array}{l}-0.000 \\
(-0.05)\end{array}$ & $\begin{array}{l}-0.015 \\
(-1.31)\end{array}$ & $\begin{array}{l}-0.015 \\
(-1.29)\end{array}$ & $\begin{array}{l}-0.006 \\
(-0.28)\end{array}$ & $\begin{array}{l}-0.005 \\
(-0.21)\end{array}$ & $\begin{array}{l}-0.005 \\
(-0.20)\end{array}$ & $\begin{array}{l}-0.002 \\
(-0.19)\end{array}$ & $\begin{array}{l}-0.014 \\
(-1.33)\end{array}$ & $\begin{array}{l}-0.017 \\
(-1.59)\end{array}$ \\
\hline $\mathrm{AGE}^{\wedge} \mathbf{2}$ & $\begin{array}{c}-0.000 * * * \\
(-6.91)\end{array}$ & $\begin{array}{l}0.000 \\
(1.50)\end{array}$ & $\begin{array}{l}0.000 \\
(1.36)\end{array}$ & $\begin{array}{l}-0.000 \\
(-1.24)\end{array}$ & $\begin{array}{l}-0.000 \\
(-1.13)\end{array}$ & $\begin{array}{l}-0.000 \\
(-1.11)\end{array}$ & $\begin{array}{l}-0.000 \\
(-0.34)\end{array}$ & $\begin{array}{l}0.000 \\
(0.17)\end{array}$ & $\begin{array}{l}0.000 \\
(0.31)\end{array}$ & $\begin{array}{c}-0.001 * * * \\
(-2.62)\end{array}$ & $\begin{array}{l}-0.000 \\
(-0.97)\end{array}$ & $\begin{array}{l}-0.000 \\
(-1.05)\end{array}$ \\
\hline $\mathrm{AGE}^{\wedge} \mathbf{3}$ & $\begin{array}{c}0.000 * * * \\
(7.93)\end{array}$ & $\begin{array}{c}0.000 * * * \\
(5.95)\end{array}$ & $\begin{array}{c}0.000 * * * \\
(5.58)\end{array}$ & $\begin{array}{l}0.000 \\
(1.20)\end{array}$ & $\begin{array}{l}0.000^{*} \\
(1.66)\end{array}$ & $\begin{array}{c}0.000^{*} \\
(1.65)\end{array}$ & $\begin{array}{l}-0.000 \\
(-1.52)\end{array}$ & $\begin{array}{c}-0.000 * * \\
(-2.10)\end{array}$ & $\begin{array}{c}-0.000 * * \\
(-2.13)\end{array}$ & $\begin{array}{l}-0.000 \\
(-1.10)\end{array}$ & $\begin{array}{l}-0.000 \\
(-0.53)\end{array}$ & $\begin{array}{l}-0.000 \\
(-0.54)\end{array}$ \\
\hline $\mathrm{AGE}^{\wedge} \mathbf{4}$ & $\begin{array}{l}-0.000 \\
(-1.54)\end{array}$ & $\begin{array}{c}-0.000 * * * \\
(-5.30)\end{array}$ & $\begin{array}{c}-0.000 * * * \\
(-4.32)\end{array}$ & $\begin{array}{l}0.000 \\
(1.24)\end{array}$ & $\begin{array}{l}0.000 \\
(1.38)\end{array}$ & $\begin{array}{l}0.000 \\
(1.21)\end{array}$ & $\begin{array}{l}0.000 \\
(1.25)\end{array}$ & $\begin{array}{l}0.000 \\
(0.89)\end{array}$ & $\begin{array}{l}0.000 \\
(0.77)\end{array}$ & $\begin{array}{l}0.000 * \\
(1.87)\end{array}$ & $\begin{array}{l}0.000 \\
(0.60)\end{array}$ & $\begin{array}{l}0.000 \\
(0.69)\end{array}$ \\
\hline $\mathbf{A G E}^{\wedge} \mathbf{5}$ & $\begin{array}{c}-0.000 * * * \\
(-3.51)\end{array}$ & $\begin{array}{c}-0.000^{* * *} \\
(-3.47)\end{array}$ & $\begin{array}{c}-0.000 * * * \\
(-3.62)\end{array}$ & $\begin{array}{l}-0.000 \\
(-0.75)\end{array}$ & $\begin{array}{l}-0.000 \\
(-0.84)\end{array}$ & $\begin{array}{l}-0.000 \\
(-0.83)\end{array}$ & $\begin{array}{c}0.000 * * * \\
(2.60)\end{array}$ & $\begin{array}{l}0.000 * * * \\
(2.73)\end{array}$ & $\begin{array}{l}0.000^{* * *} \\
(2.74)\end{array}$ & $\begin{array}{l}0.000 \\
(1.61)\end{array}$ & $\begin{array}{l}0.000 \\
(0.52)\end{array}$ & $\begin{array}{l}0.000 \\
(0.52)\end{array}$ \\
\hline TOTAL INCOME & & $\begin{array}{c}-0.000 * * * \\
(-6.11)\end{array}$ & $\begin{array}{c}-0.000 * * * \\
(-7.82)\end{array}$ & & $\begin{array}{l}-0.000 \\
(-0.32)\end{array}$ & $\begin{array}{l}-0.000 \\
(-0.31)\end{array}$ & & $\begin{array}{l}0.000 \\
(0.82)\end{array}$ & $\begin{array}{l}0.000 \\
(0.80)\end{array}$ & & $\begin{array}{l}-0.000 \\
(-0.52)\end{array}$ & $\begin{array}{l}-0.000 \\
(-1.08)\end{array}$ \\
\hline TOTAL INCOME^2 & & $\begin{array}{l}0.000 * * * \\
(5.80)\end{array}$ & $\begin{array}{l}0.000 * * * \\
(7.87)\end{array}$ & & $\begin{array}{l}-0.000 \\
(-0.31)\end{array}$ & $\begin{array}{l}-0.000 \\
(-0.32)\end{array}$ & & $\begin{array}{l}-0.000 \\
(-1.47)\end{array}$ & $\begin{array}{l}-0.000 \\
(-1.40)\end{array}$ & & $\begin{array}{l}-0.000 \\
(-0.10)\end{array}$ & $\begin{array}{l}0.000 \\
(0.44)\end{array}$ \\
\hline FT EMPLOYED & & $\begin{array}{c}0.160 * * * \\
(60.71)\end{array}$ & $\begin{array}{c}0.134 * * * \\
(45.79)\end{array}$ & & $\begin{array}{c}0.073 * * \\
(2.46)\end{array}$ & $\begin{array}{l}0.070^{* *} \\
(2.24)\end{array}$ & & $\begin{array}{l}0.060 \\
(1.24)\end{array}$ & $\begin{array}{l}0.071 \\
(1.31)\end{array}$ & & $\begin{array}{c}0.170 * * * \\
(8.02)\end{array}$ & $\begin{array}{l}0.143 * * * \\
(5.83)\end{array}$ \\
\hline PT EMPLOYED & & $\begin{array}{l}0.049 * * * \\
(9.77)\end{array}$ & $\begin{array}{c}0.025 * * * \\
(4.92)\end{array}$ & & $\begin{array}{l}-0.009 \\
(-0.27)\end{array}$ & $\begin{array}{l}-0.011 \\
(-0.38)\end{array}$ & & $\begin{array}{l}-0.062 \\
(-1.21)\end{array}$ & $\begin{array}{l}-0.055 \\
(-1.00)\end{array}$ & & $\begin{array}{l}0.006 \\
(0.20)\end{array}$ & $\begin{array}{l}-0.016 \\
(-0.53)\end{array}$ \\
\hline HIGH EDUCATION & & $\begin{array}{c}0.027 * * * \\
(7.52)\end{array}$ & $\begin{array}{c}0.020 * * * \\
(5.47)\end{array}$ & & $\begin{array}{c}0.082 * * \\
(2.32)\end{array}$ & $\begin{array}{c}0.082 * * \\
(2.31)\end{array}$ & & $\begin{array}{c}0.099 * * \\
(2.35)\end{array}$ & $\begin{array}{c}0.100^{* *} \\
(2.35)\end{array}$ & & $\begin{array}{c}0.084 * * * \\
(3.13)\end{array}$ & $\begin{array}{c}0.078 * * * \\
(2.89)\end{array}$ \\
\hline NO OF CHILDREN & & & $\begin{array}{c}-0.057 * * * \\
(-3.96)\end{array}$ & & & $\begin{array}{l}-0.060 \\
(-1.54)\end{array}$ & & & $\begin{array}{l}-0.052 \\
(-1.05)\end{array}$ & & & $\begin{array}{l}0.076 \\
(0.55)\end{array}$ \\
\hline NOT IN A COUPLE & & & $\begin{array}{c}-0.009 * * * \\
(-2.91)\end{array}$ & & & $\begin{array}{l}0.040 \\
(0.67)\end{array}$ & & & $\begin{array}{l}-0.018 \\
(-0.21)\end{array}$ & & & $\begin{array}{l}-0.014 \\
(-0.45)\end{array}$ \\
\hline HIGH SOCIAL CLASS & & & $\begin{array}{c}0.065 * * * \\
(21.51)\end{array}$ & & & $\begin{array}{l}0.014 \\
(0.46)\end{array}$ & & & $\begin{array}{l}-0.037 \\
(-0.53)\end{array}$ & & & $\begin{array}{c}0.066^{* *} \\
(2.44)\end{array}$ \\
\hline Obse & 179337 & 157679 & 157679 & 814 & 780 & 780 & 497 & 457 & 457 & 1718 & 1513 & 1513 \\
\hline Adjusted R-Squared & 0.014 & 0.032 & 0.035 & 0.1 & 0.111 & 0.108 & 0.023 & 0.044 & 0.039 & 0.021 & 0.068 & 0.07 \\
\hline
\end{tabular}

Notes: The standard errors reported in parentheses are computed using the White's heteroskedasticity estimator, $* * * \mathrm{p}<0.01, * * \mathrm{p}<0.05, * \mathrm{p}<$ 0.10 . The regression includes a fifth-order polynomial in year-of-birth. The age variable is expressed in deviations from 50.

Source: Family Resources Surveys 1994-2008. 
Table 4. Regression results on the likelihood to save, female sample.

\begin{tabular}{|c|c|c|c|c|c|c|c|c|c|c|c|c|}
\hline \multirow{3}{*}{$\begin{array}{l}\text { Dependent Variable } \\
\text { Independent Variables }\end{array}$} & \multicolumn{3}{|c|}{ WHITE } & \multicolumn{3}{|c|}{ Indian } & \multicolumn{3}{|c|}{ Pakistani } & \multicolumn{3}{|c|}{ Bangladeshi } \\
\hline & \multicolumn{12}{|c|}{ TOTAL SAVINGS D } \\
\hline & (1) & (2) & (3) & (4) & (5) & (6) & (7) & (8) & (9) & (10) & (11) & (12) \\
\hline AGE & $\begin{array}{l}-0.000 \\
(-0.04)\end{array}$ & $\begin{array}{c}-0.004 * * * \\
(-3.32)\end{array}$ & $\begin{array}{c}-0.006^{* * * *} \\
(-5.37)\end{array}$ & $\begin{array}{l}0.013 \\
(1.23)\end{array}$ & $\begin{array}{l}0.008 \\
(0.78)\end{array}$ & $\begin{array}{l}0.005 \\
(0.47)\end{array}$ & $\begin{array}{l}0.003 \\
(0.16)\end{array}$ & $\begin{array}{l}-0.003 \\
(-0.12)\end{array}$ & $\begin{array}{l}-0.013 \\
(-0.65)\end{array}$ & $\begin{array}{l}-0.012 \\
(-1.46)\end{array}$ & $\begin{array}{c}-0.026^{* * *} \\
(-2.80)\end{array}$ & $\begin{array}{c}-0.027 * * * \\
(-2.88)\end{array}$ \\
\hline $\mathrm{AGE}^{\wedge} \mathbf{2}$ & $\begin{array}{c}-0.000 * * * \\
(-6.59)\end{array}$ & $\begin{array}{l}0.000^{* * *} \\
(2.70)\end{array}$ & $\begin{array}{c}0.000^{* *} \\
(2.28)\end{array}$ & $\begin{array}{l}0.000 \\
(1.23)\end{array}$ & $\begin{array}{l}0.001^{*} \\
(1.94)\end{array}$ & $\begin{array}{c}0.001^{* *} \\
(2.03)\end{array}$ & $\begin{array}{l}0.000 \\
(0.20)\end{array}$ & $\begin{array}{l}0.000 \\
(0.85)\end{array}$ & $\begin{array}{l}0.000 \\
(1.04)\end{array}$ & $\begin{array}{c}-0.001 * * \\
(-2.14)\end{array}$ & $\begin{array}{l}-0.000 \\
(-1.32)\end{array}$ & $\begin{array}{l}-0.000 \\
(-1.21)\end{array}$ \\
\hline $\mathrm{AGE}^{\wedge} \mathbf{3}$ & $\begin{array}{c}0.000 * * * \\
(8.86)\end{array}$ & $\begin{array}{c}0.000 * * * \\
(5.66)\end{array}$ & $\begin{array}{c}0.000 * * * \\
(5.67)\end{array}$ & $\begin{array}{l}0.000 \\
(0.59)\end{array}$ & $\begin{array}{l}0.000 \\
(0.80)\end{array}$ & $\begin{array}{l}0.000 \\
(0.80)\end{array}$ & $\begin{array}{c}0.000^{*} \\
(1.92)\end{array}$ & $\begin{array}{l}0.000 \\
(1.42)\end{array}$ & $\begin{array}{c}0.000^{*} \\
(1.70)\end{array}$ & $\begin{array}{l}0.000 \\
(0.97)\end{array}$ & $\begin{array}{l}0.000 \\
(1.11)\end{array}$ & $\begin{array}{l}0.000 \\
(1.09)\end{array}$ \\
\hline $\mathrm{AGE}^{\wedge} \mathbf{4}$ & $\begin{array}{l}-0.000 \\
(-1.29)\end{array}$ & $\begin{array}{c}-0.000 * * * \\
(-6.91)\end{array}$ & $\begin{array}{c}-0.000 * * * \\
(-4.46)\end{array}$ & $\begin{array}{c}-0.000 * \\
(-1.82)\end{array}$ & $\begin{array}{l}-0.000 \\
(-1.37)\end{array}$ & $\begin{array}{c}-0.000^{*} \\
(-1.89)\end{array}$ & $\begin{array}{l}-0.000 \\
(-0.33)\end{array}$ & $\begin{array}{l}-0.000 \\
(-0.43)\end{array}$ & $\begin{array}{l}-0.000 \\
(-0.08)\end{array}$ & $\begin{array}{l}0.000^{*} \\
(1.83)\end{array}$ & $\begin{array}{l}0.000 \\
(1.20)\end{array}$ & $\begin{array}{l}0.000 \\
(1.23)\end{array}$ \\
\hline $\mathbf{A G E}^{\wedge} \mathbf{5}$ & $\begin{array}{c}-0.000 * * * \\
(-2.99)\end{array}$ & $\begin{array}{l}-0.000 \\
(-0.13)\end{array}$ & $\begin{array}{l}-0.000 \\
(-1.34)\end{array}$ & $\begin{array}{l}-0.000 \\
(-1.59)\end{array}$ & $\begin{array}{l}-0.000 \\
(-1.10)\end{array}$ & $\begin{array}{l}-0.000 \\
(-1.61)\end{array}$ & $\begin{array}{l}-0.000 \\
(-1.23)\end{array}$ & $\begin{array}{l}-0.000 \\
(-1.03)\end{array}$ & $\begin{array}{l}-0.000 \\
(-1.45)\end{array}$ & $\begin{array}{l}-0.000 \\
(-0.61)\end{array}$ & $\begin{array}{l}-0.000 \\
(-1.00)\end{array}$ & $\begin{array}{l}-0.000 \\
(-1.03)\end{array}$ \\
\hline TOTAL INCOME & & $\begin{array}{c}-0.000 * * * \\
(-7.51)\end{array}$ & $\begin{array}{c}-0.000 * * * \\
(-7.99)\end{array}$ & & $\begin{array}{l}-0.000 \\
(-0.06)\end{array}$ & $\begin{array}{l}0.000 \\
(0.04)\end{array}$ & & $\begin{array}{l}-0.000 \\
(-0.16)\end{array}$ & $\begin{array}{l}-0.000 \\
(-0.04)\end{array}$ & & $\begin{array}{l}-0.000 \\
(-0.04)\end{array}$ & $\begin{array}{l}0.000 \\
(0.10)\end{array}$ \\
\hline TOTAL INCOME^2 & & $\begin{array}{c}0.000 * * * \\
(4.78)\end{array}$ & $\begin{array}{c}0.000 * * * \\
(4.97)\end{array}$ & & $\begin{array}{c}0.000 * * \\
(2.17)\end{array}$ & $\begin{array}{c}0.000 * * \\
(2.05)\end{array}$ & & $\begin{array}{l}0.000 \\
(0.33)\end{array}$ & $\begin{array}{l}0.000 \\
(0.14)\end{array}$ & & $\begin{array}{l}-0.000 \\
(-0.13)\end{array}$ & $\begin{array}{l}-0.000 \\
(-0.42)\end{array}$ \\
\hline FT EMPLOYED & & $\begin{array}{c}0.154^{* * *} \\
(51.75)\end{array}$ & $\begin{array}{c}0.122 * * * \\
(37.68)\end{array}$ & & $\begin{array}{c}0.132 * * * \\
(2.62)\end{array}$ & $\begin{array}{l}0.077 \\
(1.41)\end{array}$ & & $\begin{array}{l}0.027 \\
(0.49)\end{array}$ & $\begin{array}{l}-0.033 \\
(-0.56)\end{array}$ & & $\begin{array}{c}0.088 * * * \\
(3.22)\end{array}$ & $\begin{array}{c}0.065^{* *} \\
(2.04)\end{array}$ \\
\hline PT EMPLOYED & & $\begin{array}{c}0.097 * * * \\
(33.93)\end{array}$ & $\begin{array}{c}0.072 * * * \\
(24.22)\end{array}$ & & $\begin{array}{c}0.106^{*} \\
(1.82)\end{array}$ & $\begin{array}{l}0.065 \\
(1.15)\end{array}$ & & $\begin{array}{r}0.060 \\
(1.08)\end{array}$ & $\begin{array}{l}0.032 \\
(0.59)\end{array}$ & & $\begin{array}{c}0.093 * * * \\
(3.37)\end{array}$ & $\begin{array}{c}0.075 * * \\
(2.53)\end{array}$ \\
\hline HIGH EDUCATION & & $0.046^{* * *}$ & $\begin{array}{c}0.036^{* * *} \\
(10.97)\end{array}$ & & $0.066^{*}$ & $\begin{array}{l}0.062^{*} \\
(1.67)\end{array}$ & & $0.070 *$ & $\begin{array}{l}0.071^{*} \\
(1.72)\end{array}$ & & $0.102 * * *$ & $\begin{array}{c}0.095 * * * \\
(3.71)\end{array}$ \\
\hline NO OF CHILDREN & & & $\begin{array}{c}-0.048 * * * \\
(-5.22)\end{array}$ & & & $\begin{array}{l}0.059 \\
(0.41)\end{array}$ & & & $\begin{array}{l}0.047 \\
(0.32)\end{array}$ & & & $\begin{array}{l}-0.052 \\
(-0.51)\end{array}$ \\
\hline NOT IN A COUPLE & & & $\begin{array}{c}-0.050 * * * \\
(-20.10)\end{array}$ & & & $\begin{array}{l}-0.051 \\
(-1.50)\end{array}$ & & & $\begin{array}{c}-0.140 * * * \\
(-4.14)\end{array}$ & & & $\begin{array}{l}-0.035 \\
(-1.52)\end{array}$ \\
\hline HIGH SOCIAL CLASS & & & $\begin{array}{c}0.068^{* * *} \\
(21.60)\end{array}$ & & & $\begin{array}{c}0.238^{* * * *} \\
(2.90)\end{array}$ & & & $\begin{array}{c}0.123^{* *} \\
(2.08)\end{array}$ & & & $\begin{array}{l}0.037 \\
(1.27)\end{array}$ \\
\hline Observations & 202,116 & 177,914 & 177,914 & 894 & 858 & 858 & 608 & 549 & 549 & 2,053 & 1,832 & 1,832 \\
\hline Adjusted R-Squared & 0.008 & 0.029 & 0.034 & 0.103 & 0.137 & 0.152 & 0.056 & 0.064 & 0.084 & 0.015 & 0.036 & 0.037 \\
\hline
\end{tabular}

Notes: The standard errors reported in parentheses are computed using the White's heteroskedasticity estimator, $* * * \mathrm{p}<0.01, * * \mathrm{p}<0.05, * \mathrm{p}<$ 0.10 . The regression includes a fifth-order polynomial in year-of-birth. The age variable is expressed in deviations from 50.

Source: Family Resources Surveys 1994-2008. 
Table 5. Regression results on savings, male sample.

\begin{tabular}{|c|c|c|c|c|c|c|c|c|c|c|c|c|}
\hline \multirow{3}{*}{$\begin{array}{l}\text { Dependent Variable: } \\
\text { Independent Variables } \\
\end{array}$} & \multicolumn{3}{|c|}{ WHITE } & \multicolumn{3}{|c|}{ Indian } & \multicolumn{3}{|c|}{ Pakistani } & \multicolumn{3}{|c|}{ Bangladeshi } \\
\hline & \multicolumn{12}{|c|}{ LN(1+TOTAL SAVINGS) } \\
\hline & (1) & (2) & (3) & (4) & (5) & (6) & $(7)$ & (8) & (9) & (10) & (11) & (12) \\
\hline AGE & $\begin{array}{c}0.075^{* * *} \\
(9.49)\end{array}$ & $\begin{array}{c}0.062 * * * \\
(6.34)\end{array}$ & $\begin{array}{l}0.067 * * * \\
(6.95)\end{array}$ & $\begin{array}{l}-0.066 \\
(-0.26)\end{array}$ & $\begin{array}{l}-0.111 \\
(-0.37)\end{array}$ & $\begin{array}{l}-0.197 \\
(-1.08)\end{array}$ & $\begin{array}{c}-0.249 * * \\
(-2.06)\end{array}$ & $\begin{array}{c}-0.378 * * * \\
(-2.75)\end{array}$ & $\begin{array}{c}-0.301 * * \\
(-2.36)\end{array}$ & $\begin{array}{l}0.129 \\
(1.52)\end{array}$ & $\begin{array}{l}-0.011 \\
(-0.10)\end{array}$ & $\begin{array}{l}-0.002 \\
(-0.02)\end{array}$ \\
\hline $\mathrm{AGE}^{\wedge} 2$ & $\begin{array}{l}-0.000 \\
(-1.18)\end{array}$ & $\begin{array}{l}-0.000 \\
(-0.05)\end{array}$ & $\begin{array}{l}0.000 \\
(0.24)\end{array}$ & $\begin{array}{c}-0.018 * * \\
(-2.07)\end{array}$ & $\begin{array}{c}-0.020^{*} \\
(-1.91)\end{array}$ & $\begin{array}{l}-0.016 \\
(-1.16)\end{array}$ & $\begin{array}{c}-0.023 * * \\
(-2.38)\end{array}$ & $\begin{array}{c}-0.028 * * \\
(-2.28)\end{array}$ & $\begin{array}{c}-0.025^{* *} \\
(-2.30)\end{array}$ & $\begin{array}{l}0.001 \\
(0.17)\end{array}$ & $\begin{array}{l}0.003 \\
(0.65)\end{array}$ & $\begin{array}{l}0.002 \\
(0.59)\end{array}$ \\
\hline $\mathbf{A G E}^{\wedge} \mathbf{3}$ & $\begin{array}{c}-0.000 * * * \\
(-2.65)\end{array}$ & $\begin{array}{c}-0.000 * * * \\
(-2.83)\end{array}$ & $\begin{array}{c}-0.000 * * \\
(-1.97)\end{array}$ & $\begin{array}{l}0.001^{*} \\
(1.80)\end{array}$ & $\begin{array}{l}0.001 \\
(1.61)\end{array}$ & $\begin{array}{l}0.001 \\
(1.55)\end{array}$ & $\begin{array}{c}-0.001 * * \\
(-2.38)\end{array}$ & $\begin{array}{c}-0.001 * \\
(-1.72)\end{array}$ & $\begin{array}{l}-0.000 \\
(-1.52)\end{array}$ & $\begin{array}{c}0.000^{* *} \\
(2.01)\end{array}$ & $\begin{array}{c}0.000^{* *} \\
(2.26)\end{array}$ & $\begin{array}{c}0.000^{* *} \\
(2.26)\end{array}$ \\
\hline$A G E^{\wedge} 4$ & $\begin{array}{l}0.000 \\
(1.41)\end{array}$ & $\begin{array}{l}0.000 \\
(1.18)\end{array}$ & $\begin{array}{c}-0.000 * * \\
(-2.09)\end{array}$ & $\begin{array}{l}0.000 \\
(0.06)\end{array}$ & $\begin{array}{l}0.000 \\
(0.22)\end{array}$ & $\begin{array}{l}-0.000 \\
(-0.16)\end{array}$ & $\begin{array}{c}0.000^{* *} \\
(2.30)\end{array}$ & $\begin{array}{c}0.000^{* *} \\
(2.53)\end{array}$ & $\begin{array}{c}0.000 * * \\
(2.35)\end{array}$ & $\begin{array}{l}-0.000 \\
(-0.44)\end{array}$ & $\begin{array}{l}-0.000 \\
(-1.29)\end{array}$ & $\begin{array}{l}-0.000 \\
(-1.25)\end{array}$ \\
\hline $\mathrm{AGE}^{\wedge} 5$ & $\begin{array}{l}0.000 \\
(0.93)\end{array}$ & $\begin{array}{l}0.000 \\
(0.87)\end{array}$ & $\begin{array}{c}0.000 * * \\
(2.01)\end{array}$ & $\begin{array}{l}-0.000 \\
(-1.44)\end{array}$ & $\begin{array}{l}-0.000 \\
(-0.82)\end{array}$ & $\begin{array}{l}-0.000 \\
(-1.12)\end{array}$ & $\begin{array}{c}0.000^{* *} \\
(2.46)\end{array}$ & $\begin{array}{c}0.000 * * \\
(2.62)\end{array}$ & $\begin{array}{c}0.000 * * \\
(2.43)\end{array}$ & $\begin{array}{c}-0.000 * * \\
(-2.17)\end{array}$ & $\begin{array}{c}-0.000 * * * \\
(-2.77)\end{array}$ & $\begin{array}{c}-0.000 * * \\
(-2.50)\end{array}$ \\
\hline TOTAL INCOME & & $\begin{array}{c}0.000 * * * \\
(8.65)\end{array}$ & $\begin{array}{c}0.000 * * * \\
(8.76)\end{array}$ & & $\begin{array}{l}0.002 \\
(0.94)\end{array}$ & $\begin{array}{l}0.003 \\
(1.07)\end{array}$ & & $\begin{array}{l}0.001 \\
(0.33)\end{array}$ & $\begin{array}{l}0.002 \\
(1.00)\end{array}$ & & $\begin{array}{c}0.002^{* *} \\
(2.18)\end{array}$ & $\begin{array}{c}0.002 * * \\
(2.08)\end{array}$ \\
\hline TOTAL INCOME^2 & & $\begin{array}{c}-0.000 * * * \\
(-7.20)\end{array}$ & $\begin{array}{c}-0.000 * * * \\
(-7.28)\end{array}$ & & $\begin{array}{c}-0.000^{*} \\
(-1.81)\end{array}$ & $\begin{array}{c}-0.000^{*} \\
(-1.96)\end{array}$ & & $\begin{array}{l}-0.000 \\
(-0.22)\end{array}$ & $\begin{array}{l}-0.000 \\
(-0.66)\end{array}$ & & $\begin{array}{c}-0.000^{*} \\
(-1.96)\end{array}$ & $\begin{array}{c}-0.000^{*} \\
(-1.93)\end{array}$ \\
\hline FT EMPLOYED & & $\begin{array}{l}-0.175 \\
(-0.78)\end{array}$ & $\begin{array}{l}-0.160 \\
(-0.84)\end{array}$ & & $\begin{array}{l}-0.040 \\
(-0.07)\end{array}$ & $\begin{array}{l}-0.022 \\
(-0.04)\end{array}$ & & $\begin{array}{l}-0.359 \\
(-1.14)\end{array}$ & $\begin{array}{l}0.307 \\
(0.88)\end{array}$ & & $\begin{array}{l}-0.780 \\
(-1.14)\end{array}$ & $\begin{array}{l}-0.786 \\
(-1.07)\end{array}$ \\
\hline PT EMPLOYED & & $\begin{array}{l}-0.023 \\
(-0.45)\end{array}$ & $\begin{array}{l}-0.037 \\
(-0.74)\end{array}$ & & $\begin{array}{l}0.683 \\
(0.94)\end{array}$ & $\begin{array}{l}0.906 \\
(1.20)\end{array}$ & & $\begin{array}{l}-0.045 \\
(-0.08)\end{array}$ & $\begin{array}{l}-0.007 \\
(-0.01)\end{array}$ & & $\begin{array}{l}-0.121 \\
(-0.25)\end{array}$ & $\begin{array}{l}-0.172 \\
(-0.33)\end{array}$ \\
\hline HIGH EDUCATION & & $\begin{array}{c}0.080^{* *} \\
(2.53)\end{array}$ & $\begin{array}{c}0.085 * * * \\
(2.75)\end{array}$ & & $\begin{array}{l}0.309 \\
(0.59)\end{array}$ & $\begin{array}{l}0.358 \\
(0.66)\end{array}$ & & $\begin{array}{l}0.250 \\
(0.59)\end{array}$ & $\begin{array}{l}0.413 \\
(0.97)\end{array}$ & & $\begin{array}{l}0.530 \\
(1.11)\end{array}$ & $\begin{array}{l}0.444 \\
(0.92)\end{array}$ \\
\hline NO OF CHILDREN & & & $\begin{array}{c}-0.292^{*} \\
(-1.73)\end{array}$ & & & $\begin{array}{c}0.000 \\
(.)\end{array}$ & & & $\begin{array}{c}0.000 \\
(.)\end{array}$ & & & $\begin{array}{l}-0.116 \\
(-0.32)\end{array}$ \\
\hline NOT IN A COUPLE & & & $\begin{array}{c}0.909 * * * \\
(41.64)\end{array}$ & & & $\begin{array}{l}-1.124 \\
(-1.24)\end{array}$ & & & $\begin{array}{c}1.223 * * \\
(2.61)\end{array}$ & & & $\begin{array}{l}0.298 \\
(0.78)\end{array}$ \\
\hline HIGH SOCIAL CLASS & & & $\begin{array}{c}0.084 * * * \\
(3.61)\end{array}$ & & & $\begin{array}{l}-0.312 \\
(-0.40)\end{array}$ & & & $\begin{array}{c}1.191^{* * *} \\
(3.43)\end{array}$ & & & $\begin{array}{l}0.144 \\
(0.48)\end{array}$ \\
\hline Observations & 45,724 & 40,171 & 40,171 & 111 & 110 & 110 & 95 & 87 & 87 & 288 & 255 & 255 \\
\hline Adjusted R-Squared & 0.021 & 0.021 & 0.054 & 0.021 & 0.055 & 0.047 & 0.141 & 0.073 & 0.156 & 0.062 & 0.08 & 0.071 \\
\hline
\end{tabular}

Notes: The standard errors reported in parentheses are computed using the White's heteroskedasticity estimator, $* * * \mathrm{p}<0.01, * * \mathrm{p}<0.05, * \mathrm{p}<$ 0.10 . The regression includes a fifth-order polynomial in year-of-birth. The age variable is expressed in deviations from 50.

Source: Family Resources Surveys 1994-2008. 
Table 6. Regression results on savings, female sample.

\begin{tabular}{|c|c|c|c|c|c|c|c|c|c|c|c|c|}
\hline \multirow{3}{*}{$\begin{array}{l}\text { Dependent Variable } \\
\text { Independent Variables }\end{array}$} & \multicolumn{3}{|c|}{ WHITE } & \multicolumn{3}{|c|}{ Indian } & \multicolumn{3}{|c|}{ Pakistani } & \multicolumn{3}{|c|}{ Bangladeshi } \\
\hline & \multicolumn{12}{|c|}{ LN(1+TOTAL SAVINGS) } \\
\hline & (1) & (2) & (3) & (4) & (5) & (6) & (7) & (8) & (9) & (10) & (11) & (12) \\
\hline \multirow[t]{2}{*}{ AGE } & $0.050 * * *$ & 0.008 & 0.008 & $-0.524 *$ & $-0.649 * *$ & -0.067 & -0.007 & 0.103 & 0.253 & 0.135 & -0.020 & 0.060 \\
\hline & $(6.78)$ & $(0.93)$ & $(0.98)$ & $(-1.83)$ & $(-2.28)$ & $(-0.25)$ & $(-0.02)$ & $(0.22)$ & $(0.49)$ & $(1.19)$ & $(-0.12)$ & $(0.40)$ \\
\hline \multirow[t]{2}{*}{$\mathrm{AGE}^{\wedge} \mathbf{2}$} & -0.000 & $0.000^{*}$ & $0.000 * *$ & 0.006 & 0.008 & 0.013 & -0.034 & -0.014 & -0.005 & 0.002 & 0.000 & -0.002 \\
\hline & $(-1.04)$ & $(1.89)$ & $(2.02)$ & $(0.24)$ & $(0.31)$ & $(1.29)$ & $(-1.03)$ & $(-0.33)$ & $(-0.12)$ & $(0.67)$ & $(0.07)$ & $(-0.44)$ \\
\hline \multirow[t]{2}{*}{$\mathrm{AGE}^{\wedge} \mathbf{3}$} & 0.000 & $-0.000 *$ & $-0.000 *$ & $0.001 * *$ & $0.002 * *$ & 0.001 & -0.000 & -0.000 & -0.000 & -0.000 & -0.000 & -0.000 \\
\hline & $(0.01)$ & $(-1.75)$ & $(-1.83)$ & $(2.32)$ & $(2.59)$ & $(1.36)$ & $(-0.97)$ & $(-0.37)$ & $(-0.57)$ & $(-0.31)$ & $(-0.13)$ & $(-0.13)$ \\
\hline \multirow[t]{2}{*}{$\mathrm{AGE}^{\wedge} 4$} & 0.000 & 0.000 & -0.000 & -0.000 & -0.000 & -0.000 & 0.000 & 0.000 & -0.000 & -0.000 & 0.000 & 0.000 \\
\hline & $(1.37)$ & $(1.21)$ & $(-0.85)$ & $(-0.36)$ & $(-0.31)$ & $(-1.53)$ & $(0.98)$ & $(0.34)$ & $(-0.03)$ & $(-0.41)$ & $(0.27)$ & $(0.54)$ \\
\hline \multirow[t]{2}{*}{$\mathrm{AGE}^{\wedge} 5$} & -0.000 & -0.000 & 0.000 & -0.000 & -0.000 & $-0.000 * *$ & 0.000 & 0.000 & 0.000 & 0.000 & -0.000 & -0.000 \\
\hline & $(-0.64)$ & $(-0.48)$ & $(1.22)$ & $(-1.01)$ & $(-0.95)$ & $(-2.21)$ & $(0.92)$ & $(0.35)$ & $(0.05)$ & $(0.07)$ & $(-0.19)$ & $(-0.05)$ \\
\hline \multirow[t]{2}{*}{ TOTAL INCOME } & & $0.002 * * *$ & $0.001 * * *$ & & $0.006 * * *$ & $0.006^{* * *}$ & & $0.006^{* *}$ & $0.006^{* *}$ & & $0.003^{*}$ & 0.002 \\
\hline & & (18.96) & (16.18) & & (3.77) & (3.95) & & $(2.40)$ & $(2.58)$ & & $(1.75)$ & $(1.33)$ \\
\hline \multirow[t]{2}{*}{ TOTAL INCOME^2 } & & $-0.000 * * *$ & $-0.000 * * *$ & & $-0.000 * * *$ & $-0.000 * * *$ & & $-0.000 *$ & $-0.000 *$ & & -0.000 & -0.000 \\
\hline & & $(-6.25)$ & $(-5.94)$ & & $(-4.55)$ & $(-4.77)$ & & $(-1.87)$ & $(-1.93)$ & & $(-1.11)$ & $(-0.92)$ \\
\hline \multirow[t]{2}{*}{ FT EMPLOYED } & & -0.214 & -0.209 & & -0.504 & -0.703 & & -0.347 & -0.311 & & -0.074 & -0.331 \\
\hline & & $(-1.25)$ & $(-1.06)$ & & $(-1.16)$ & $(-1.52)$ & & $(-0.77)$ & $(-0.51)$ & & $(-0.22)$ & $(-1.01)$ \\
\hline \multirow[t]{2}{*}{ PT EMPLOYED } & & -0.144 & -0.132 & & -0.452 & -0.567 & & -0.732 & -0.623 & & -0.053 & -0.254 \\
\hline & & $(-0.62)$ & $(-0.87)$ & & $(-1.08)$ & $(-1.33)$ & & $(-1.05)$ & $(-0.83)$ & & $(-0.16)$ & $(-0.76)$ \\
\hline \multirow[t]{2}{*}{ HIGH EDUCATION } & & $0.314 * * *$ & $0.308 * * *$ & & -0.159 & -0.146 & & 0.201 & 0.172 & & 0.834 & 0.319 \\
\hline & & (11.28) & (11.12) & & $(-0.46)$ & $(-0.42)$ & & $(0.30)$ & $(0.24)$ & & $(1.40)$ & $(0.66)$ \\
\hline \multirow[t]{2}{*}{ NO OF CHILDREN } & & & $-0.311 * *$ & & & $-4.673 * * *$ & & & -0.389 & & & $-6.438 * * *$ \\
\hline & & & $(-2.39)$ & & & $(-11.36)$ & & & $(-0.44)$ & & & $(-10.70)$ \\
\hline \multirow[t]{2}{*}{ NOT IN A COUPLE } & & & $0.647 * * *$ & & & $1.298 * *$ & & & $2.873 * * *$ & & & $0.954 * * *$ \\
\hline & & & $(33.64)$ & & & $(2.61)$ & & & $(3.38)$ & & & $(3.80)$ \\
\hline \multirow[t]{2}{*}{ HIGH SOCIAL CLASS } & & & $0.080 * * *$ & & & 0.364 & & & 0.016 & & & $0.559 * *$ \\
\hline & & & $(3.43)$ & & & $(0.51)$ & & & $(0.03)$ & & & $(2.24)$ \\
\hline Observations & 49499 & 43609 & 43609 & 115 & 115 & 115 & 99 & 89 & 89 & 331 & 296 & 296 \\
\hline Adjusted R-Squared & 0.052 & 0.074 & 0.094 & 0.02 & 0.119 & 0.182 & -0.03 & -0.003 & -0.012 & 0.017 & 0.049 & 0.114 \\
\hline
\end{tabular}

Notes: The standard errors reported in parentheses are computed using the White's heteroskedasticity estimator, $* * * \mathrm{p}<0.01, * * \mathrm{p}<0.05, * \mathrm{p}<$ 0.10 . The regression includes a fifth-order polynomial in year-of-birth. The age variable is expressed in deviations from 50.

Source: Family Resources Surveys 1994-2008 
Figure 1a. Saving participation ratios, male sample

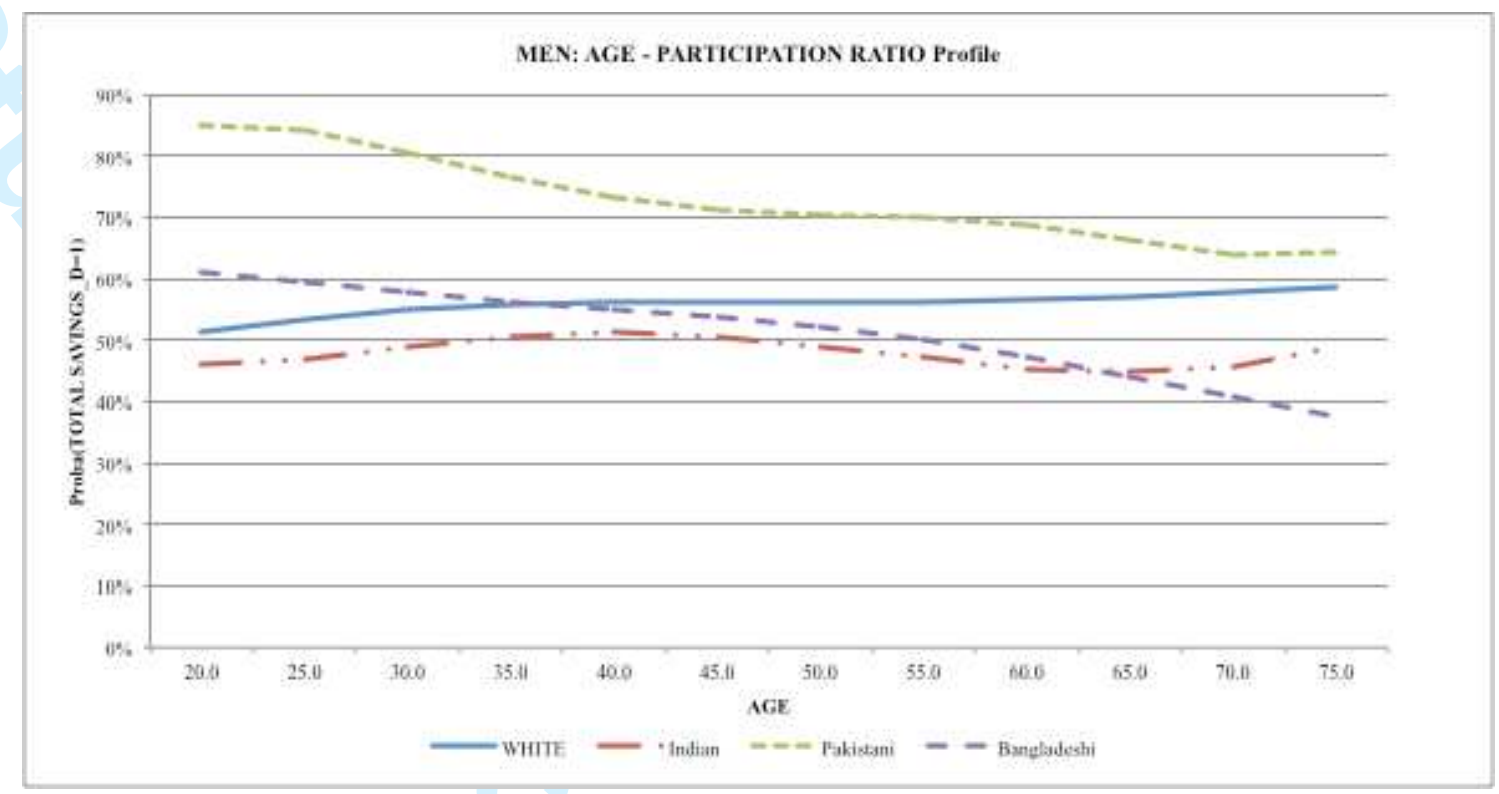

Notes: The minimum and maximum ages represented here are 20 and 75 respectively, owing to the lack of data for respondents younger than 20 and older than 75 .

Figure 1b. Saving participation ratios, female sample

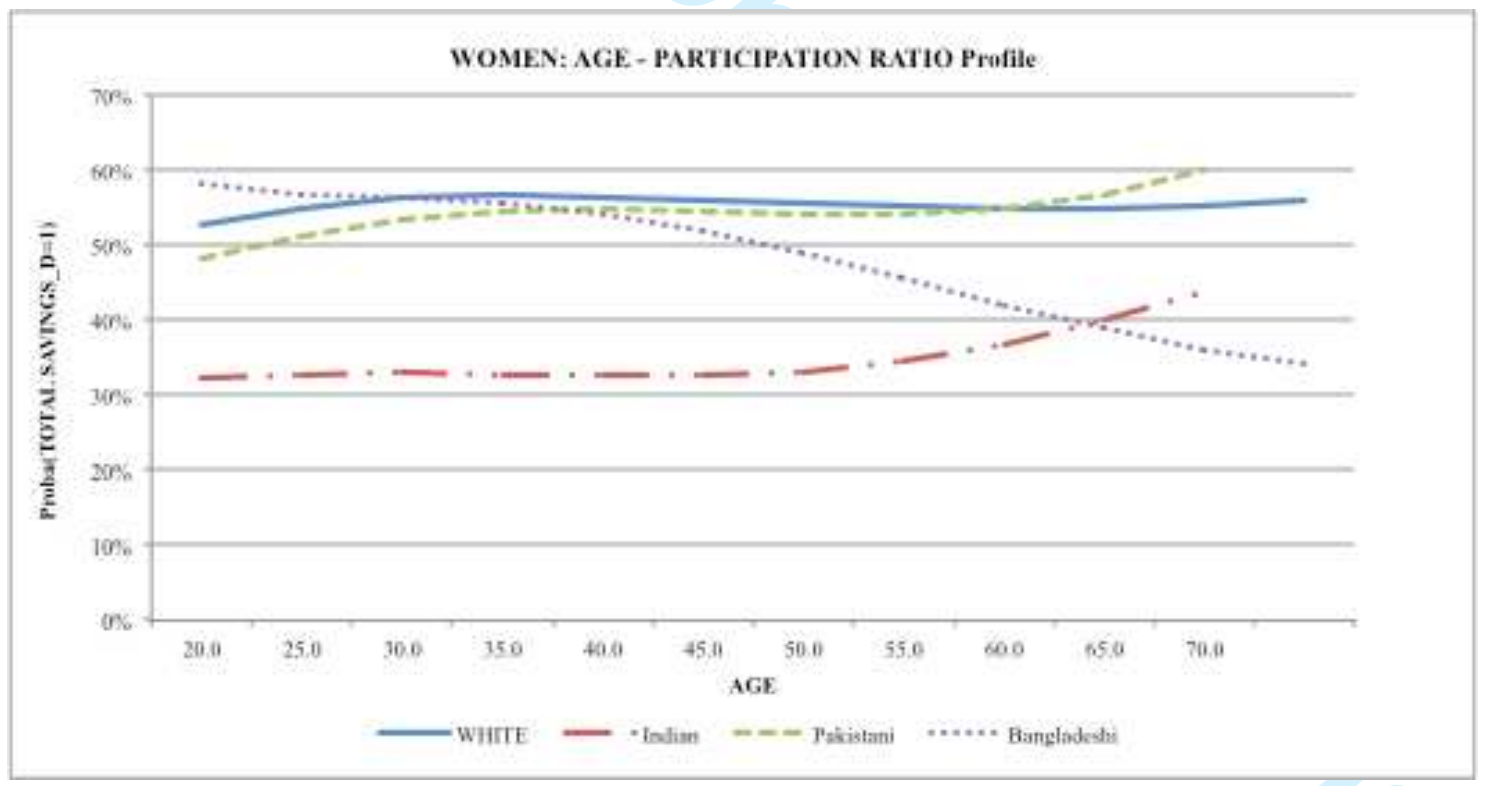

Notes: The minimum and maximum ages represented here are 20 and 75 respectively, owing to the lack of data for respondents younger than 20 and older than 75.The graph for Pakistani and Indian women stops at the age of 70 owing to the lack of observations beyond that age in our sample 
Figure 2a. Saving profiles against age, male sample

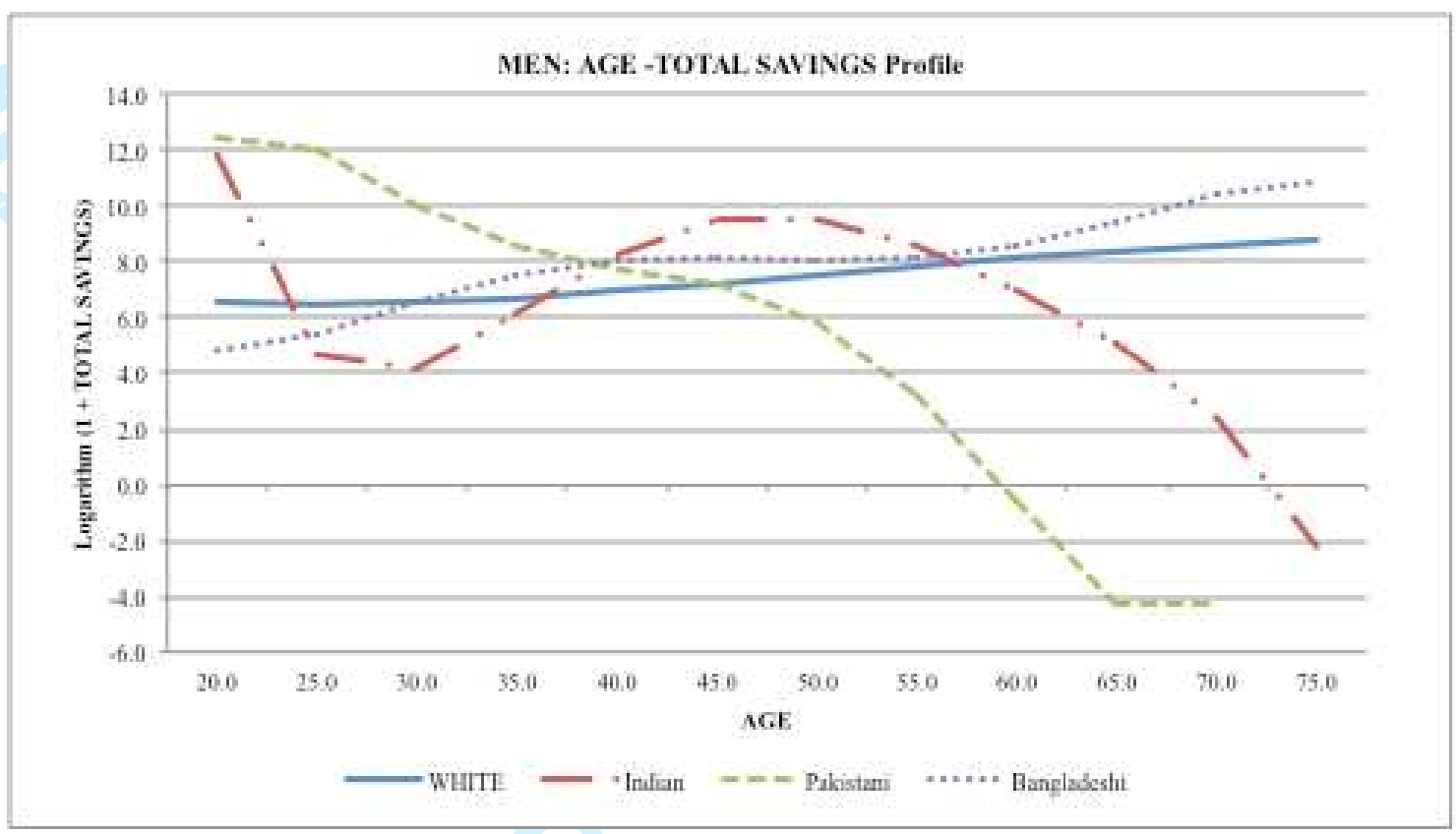

Notes: The minimum and maximum ages represented here are 20 and 75 respectively, owing to the lack of data for respondents younger than 20 and older than 75 . The graph for Pakistani men stops at the age of 70 , owing to the lack of observations beyond that age in our sample.

Figure 2b. Saving profiles against age, female sample

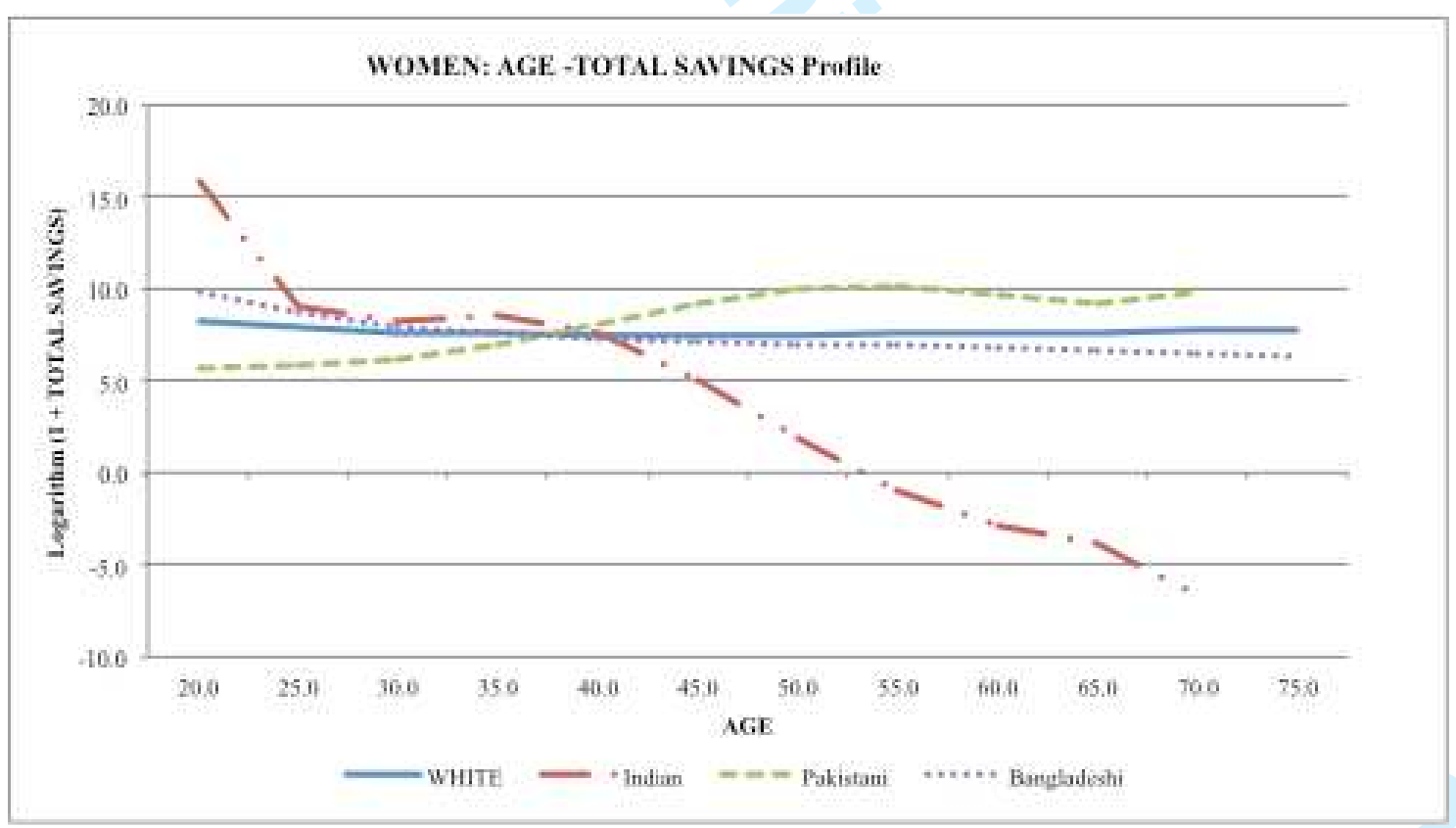

Notes: The minimum and maximum ages represented here are 20 and 75 respectively, owing to the lack of data for respondents younger than 20 and older than 75 .

The graph for Pakistani and Indian women stops at the age of 70 owing to the lack of observations beyond that age in our sample. 